\title{
Long-term Implications of Sustained Wind Power Growth in the United States: Potential Benefits and Secondary Impacts
}

\author{
Ryan Wiser ${ }^{a, *}$, Mark Bolinger ${ }^{b}$, Garvin Heath ${ }^{c}$, David Keyser ${ }^{d}$, Eric Lantz ${ }^{e}$, Jordan Macknick ${ }^{f}$, Trieu Mais, \\ Dev Millstein ${ }^{h}$ \\ aLawrence Berkeley National Laboratory, 1 Cyclotron Road, MS 90-4000, Berkeley, CA 94720, USA, \\ rhwiser@lbl.gov \\ 'Lawrence Berkeley National Laboratory, 1 Cyclotron Road, MS 90-4000, Berkeley, CA 94720, USA, \\ mabolinger@lbl.gov \\ 'National Renewable Energy Laboratory, 15013 Denver West Parkway, Golden, CO 80401, USA, \\ garvin.heath@nrel.gov \\ ${ }^{d}$ National Renewable Energy Laboratory, 15013 Denver West Parkway, Golden, CO 80401, USA, \\ david.keyser@nrel.gov \\ 'National Renewable Energy Laboratory, 15013 Denver West Parkway, Golden, CO 80401, USA, \\ eric.lantz@nrel.gov \\ fNational Renewable Energy Laboratory, 15013 Denver West Parkway, Golden, CO 80401, USA, \\ Jordan.macknick@nrel.gov \\ ${ }^{g}$ National Renewable Energy Laboratory, 15013 Denver West Parkway, Golden, CO 80401, USA, \\ trieu.mai@nrel.gov \\ hLawrence Berkeley National Laboratory, 1 Cyclotron Road, MS 90-4000, Berkeley, CA 94720, USA, \\ dmillstein@lbl.gov
}

*Corresponding author:

Dr. Ryan Wiser

Lawrence Berkeley National Laboratory

1 Cyclotron Road, MS 90-4000

Berkeley, California 94720, USA

e-mail: rhwiser@lbl.gov

Phone: 510-486-5474

(C) 2016. This manuscript version is made available under the Elsevier user license 


\begin{abstract}
We model scenarios of the U.S. electric sector in which wind generation reaches $10 \%$ of end-use electricity demand in $2020,20 \%$ in 2030 , and $35 \%$ in 2050 . As shown in a companion paper, achieving these penetration levels would have significant implications for the wind industry and the broader electric sector. Compared to a baseline that assumes no new wind deployment, under the primary scenario modeled, achieving these penetrations imposes an incremental cost to electricity consumers of less than $1 \%$ through 2030. These cost implications, however, should be balanced against the variety of environmental and social implications of such a scenario. Relative to a baseline that assumes no new wind deployment, our analysis shows that the high-penetration wind scenario yields potential greenhouse-gas benefits of $\$ 85-\$ 1,230$ billion in present-value terms, with a central estimate of $\$ 400$ billion. Air-pollution-related health benefits are estimated at $\$ 52-\$ 272$ billion, while annual electricsector water withdrawals and consumption are lower by $15 \%$ and $23 \%$ in 2050 , respectively. We also find that a high-wind-energy future would have implications for the diversity and risk of energy supply, local economic development, and land use and related local impacts on communities and ecosystems; however, these additional impacts may not greatly affect aggregate social welfare owing to their nature, in part, as resource transfers.
\end{abstract}

\title{
Keywords:
}

Wind energy

Co-benefits

Greenhouse gases

Air pollution

Water use

\section{Introduction}

Wind energy's role in global (GWEC 2015) and U.S. (Wiser and Bolinger 2014) electricity supply is rising, driven by policy measures as well as technology advancements and associated cost reductions (IPCC 2011). The underlying policies helping motivate growth in wind energy are often predicated on the stated benefits of wind energy relative to fossil energy sources, including carbon and air-pollution emissions reductions, limited or no water requirements, potential benefits from energy diversity and risk reduction, and local economic-development activity. These benefits, however, are not always evaluated quantitatively, described fully, or qualified appropriately. Moreover, wind's benefits must be compared with the potential costs and risks introduced by adding wind energy to the electric systemsuch as changes in energy costs and increased planning and operating reserve requirements-as well as the potential negative impacts of wind on local ecosystems, local communities, and economic development elsewhere in the economy.

Transitioning to a future electricity system in which wind plays a more prominent role will have direct and significant impacts on the wind industry, cascading effects through the rest of the electricity system, and implications for local and global environments, human health, and the broader economy. In this and a companion paper (Lantz et al. forthcoming), we evaluate these myriad potential impacts, costs, and benefits within the context of a Wind Vision scenario in which wind energy increases from its 2013 contribution of $4.5 \%$ of U.S. annual electricity demand to $10 \%$ by $2020,20 \%$ by 2030 , and $35 \%$ by 2050 . As described in DOE (2015), we view this modeled scenario as plausible but ambitious. We then compare this scenario with an alternative baseline scenario that assumes no new wind deployment. 
The analysis described here assesses the potential implications of achieving a high-wind future. Lantz et al. (forthcoming) and DOE (2015) summarize the electric-sector modeling approach and its advantages and limitations, the scenario framework, and the key input assumptions; the envisioned transitions to future power systems based on scenario results; direct electric-sector costs and impacts on electricity consumers; and transmission-expansion and grid-integration needs. The current paper analyzes a subset of the possible environmental and social co-benefits, co-costs, and co-impacts of this high-wind scenario. Specifically, it covers greenhouse-gas (GHG) emissions reductions, air-pollution impacts, wateruse reduction, energy diversity and risk reduction, workforce and economic-development impacts, and land-use and local impacts. Table 1 summarizes, in brief, the impacts covered, methods used, and key caveats that apply to our analysis.

Table 1. Summary of Co-Benefits, Co-Costs, and Co-Impacts Covered in Analysis

\begin{tabular}{|c|c|}
\hline Category & Brief Description \\
\hline $\begin{array}{l}\text { Greenhouse-Gas } \\
\text { Emissions Reductions }\end{array}$ & $\begin{array}{l}\text { Coverage and Method: Quantifies life-cycle GHG emissions reductions, and values } \\
\text { those reductions based on "social cost of carbon (SCC)" estimates. } \\
\text { Caveats and Limitations: Considerable uncertainty exists on the SCC, so } 4 \text { trajectories } \\
\text { spanning a wide range are applied; these reflect global carbon damage estimates. }\end{array}$ \\
\hline Air-Pollution Impacts & $\begin{array}{l}\text { Coverage and Method: Estimates combustion-related criteria air pollution emissions } \\
\text { reductions, and values those reductions based on avoided health outcomes. } \\
\text { Caveats and Limitations: Focuses on } 3 \text { combustion-related pollutants; given } \\
\text { uncertainty, develops } 3 \text { benefit estimates; assumes presence of MATS and CSAPR. }\end{array}$ \\
\hline Water Use Reduction & $\begin{array}{l}\text { Coverage and Method: Estimates operational water withdrawal and consumption } \\
\text { impacts, including on a regional basis, and discusses benefits qualitatively. } \\
\text { Caveats and Limitations: Does not quantify monetary value of water use reductions; } \\
\text { makes assumptions about cooling-technology requirements for new power plants. }\end{array}$ \\
\hline $\begin{array}{l}\text { Energy Diversity and Risk } \\
\text { Reduction }\end{array}$ & $\begin{array}{l}\text { Coverage and Method: Estimates impacts based on: (1) reduced sensitivity of future } \\
\text { electric-system costs to uncertain fuel prices; and (2) reduced natural gas prices. } \\
\text { Caveats and Limitations: Generalized methods to value diversity and risk reduction are } \\
\text { controversial; neither impact estimated here represents a societal benefit. }\end{array}$ \\
\hline $\begin{array}{l}\text { Workforce and Economic } \\
\text { Development }\end{array}$ & $\begin{array}{l}\text { Coverage and Method: Estimates gross wind-related employment needs, based on } \\
\text { input-output model. } \\
\text { Caveats and Limitations: Develops } 2 \text { estimates based on range of manufacturing } \\
\text { assumptions; does not consider net impacts, and no societal benefit claimed. }\end{array}$ \\
\hline $\begin{array}{l}\text { Land Use and Local } \\
\text { Impacts }\end{array}$ & $\begin{array}{l}\text { Coverage and Method: Estimates land requirements from wind deployment } \\
\text { considering wind project boundaries and the amount of disturbed land within that. } \\
\text { Caveats and Limitations: Does not consider net impacts given reduced land needs } \\
\text { associated with displaced generation; qualitatively discusses other local impacts. }\end{array}$ \\
\hline
\end{tabular}

Our research uses a scenario-analysis approach where the 10\%/20\%/35\% Wind Vision "study" scenario is compared with a "baseline" scenario in which no new wind is deployed post-2013. Though somewhat unconventional, this framework enables us to assess the costs, benefits, and impacts of all incremental wind deployment beyond 2013. Whereas Lantz et al. (forthcoming) and DOE (2015) evaluate these scenarios (as well as more-traditional business-as-usual scenarios) using the National Renewable Energy Laboratory's (NREL) ReEDS model under a range of future fossil and wind energy costs, the present paper focuses on the central study assumptions. For each benefit, impact, and cost category, we take the modeled output from the ReEDS capacity-expansion model and then apply additional tools to assess benefits, costs, and impacts in physical and, where feasible, monetary terms. We qualify the study results appropriately-highlighting areas of uncertainty-and objectively address their policy implications. The U.S. Department of Energy's Wind Vision report provides further detail on the assumptions, methods, and results (DOE 2015), as does the companion paper by Lantz et al. 
(forthcoming). In particular, see Lantz et al. (forthcoming) for a summary of the ReEDS model and why that model is well-suited for the present analysis, and for more information on the remaining limitations and uncertainties in both the modeling approach and assumptions.

The approach used in the present study contributes to and builds on past literature. Previous work has found that the increasing maturity of wind technology (Wiser et al. 2011) and the size of the global resource (Marvel et al. 2012) could enable wind energy to play a significant future role in electricity supply (Barthelmie and Pryor 2014; Cochran et al. 2014; IPCC 2014b; Luderer et al. 2014; Zhang et al. 2016). That role, however, is uncertain, and is found to be affected by wind energy cost reductions, the scale of greenhouse gas emissions mitigation efforts, and other factors (IPCC 2014b; Luderer et al. 2014; Zhang et al. 2016). Some of this research has focused specifically on wind energy's role in the U.S. electricity mix. MacDonald et al. (2016), for example, find significant potential for wind energy supply in the U.S., as does an earlier report from the U.S. Department of Energy (DOE 2008).

Other past research has explored a subset of the potential benefits and impacts of wind energy. For example, McCubbin and Sovacool (2013) compare the health and environmental impacts of wind to natural gas, while Yang and Chen (2016) provide a sustainability evaluation of wind power systems. Siler-Evans et al. (2013), Buonocore et al. (2016), and Cullen (2013) explore these health and climate benefits on a regional basis, while Arent et al. (2014) assess a small subset of benefits associated with a high-penetration renewable energy scenario in the U.S. primarily in physical (not financial) terms. Others have explored the impacts of renewable (and wind) energy deployment on water use, on land use, on risk and diversity, and on employment - with citations provided later in this paper.

The present work and that described in Lantz et al. (forthcoming) substantially builds on these past efforts in several ways. First, and most importantly, ours is a comprehensive assessment of important impacts, costs, and benefits of a high-penetration wind energy future. Rather than focusing on a small subset of important decision variables, as much of the previous literature has, we instead seek to combine and apply myriad state-of-the-art methods to fully describe the most-important effects spanning environmental, public health, economic, and consumer impacts - of a high-penetration wind energy future (see Table 1 and Lantz et al. [forthcoming]). Second, in conducting our analysis, we use recent assumptions about wind and fossil energy costs, including a range of assumptions for each, ensuring that our results are current and reflect the underlying uncertainties involved. Third, we rely on an electric sector model that contains the spatial and temporal detail necessary to accurately assess high wind energy penetration futures on not only a national but also a regional basis, and we utilize state-ofthe-art methods to assess the benefits and impacts that derive from that future in physical and (where feasible) economic terms. Finally, we carefully discuss the uncertainties and limitations to the estimates from our analysis, enabling decision-makers and analysts to understand fully the results described.

Sections 2 through 5 of this paper describe the issues, analysis approaches, and results associated with each benefit/cost/impact category. We conclude in Section 6, contrasting the results presented in this paper with the possible costs described in Lantz et al. (forthcoming) and highlighting the key implications and limitations of the analysis in informing policy decisions.

\section{Greenhouse-Gas Emissions Reductions}

\subsection{Overview}

Most scientists agree that significant changes will occur to Earth's climate due to anthropogenic GHG emissions. These changes may include rising average temperatures, increased frequency and intensity of 
some types of extreme weather, rising sea levels due to both thermal expansion and ice melt, and ocean acidification (IPCC 2007a; IPCC 2007c; IPCC 2013; IPCC 2014a; Melillo et al. 2014). In part as a result, there is growing agreement on the desirability of near-term actions to reduce GHG emissions (IPCC 2014b; Jakob et al. 2012; Luderer et al. 2013; Nordhaus 2013). Wind power is one technology that could reduce GHG emissions and thus decrease the likelihood and severity of future climate-related damages and associated costs (IPCC 2014a; IPCC 2014b). Additionally, near-term action to limit GHGs may reduce the longer-term cost of meeting future policies intended to reduce GHGs (Luckow et al. 2013).Some U.S. states have already enacted carbon policies (Luckow et al. 2013); the U.S. Congress has considered such policies in the past (Luckow et al. 2013); and the U.S. Environmental Protection Agency (EPA) has proposed emission limits for power plants (EPA 2014). As a result, many utilities already regularly consider the possibility of future policies to reduce GHGs in resource planning, and thereby treat wind and other low-carbon technologies as options for reducing the possible future costs of climate mitigation (Barbose et al. 2008; Bokenkamp et al. 2005).

\subsection{Methods}

This section first estimates the potential GHG reductions associated with the Study Scenario compared to the no-new-wind Baseline Scenario. It then quantifies the economic benefits of these GHG reductions based on a range of social cost of carbon (SCC) estimates. These methods are broadly consistent with those used by U.S. regulatory agencies (GAO 2014) and academic researchers (Cullen 2013; Graff Zivin et al. 2014; Johnson et al. 2013; Kaffine et al. 2013; McCubbin and Sovacool 2013; Novan 2014; Siler-Evans et al. 2013, Schindell 2015).

We use output from the ReEDS capacity-expansion model to estimate combustion-related GHG emissions. However, combustion-related estimates ignore full lifecycle considerations. First, only $\mathrm{CO}_{2}$ emissions are considered, while other potent GHGs are ignored, an omission that may be particularly important for methane released in coal mining, oil production, and natural gas production and transport. Second, a focus on combustion-only emissions means GHG emissions from upstream fuel extraction and processing, equipment manufacturing and construction, operations and maintenance, and plant decommissioning are not considered for wind or other power plants. Therefore, we adjust these figures to estimate lifecycle impacts by combining ReEDS combustion-related emissions with lifecycle, non-combustion emission values for each generation technology. Non-combustion lifecycle emission estimates were developed through a comprehensive literature assessment. For further details, see DOE (2015) and Mai et al. (2012). ${ }^{1}$

We then estimate the economic benefits of wind due to limiting climate-change damages using the SCC. The SCC reflects, among other elements, monetary damages resulting from the impacts of climate change on agricultural productivity, human health, property damages, and ecosystem services (IWG 2010; IWG 2013). Considerable research tackles the challenge of estimating the magnitude and timing of climate-change impacts, damages, and associated costs (IPCC 2007a; IPCC 2007b; IPCC 2014a; IPCC 2014b; IWG 2010; IWG 2013; Melillo et al. 2014; Weitzman 2012). Because of the uncertainties involved, a number of widely ranging estimates of the SCC are available (IPCC 2007b; IPCC 2014b; Tol 2011).

\footnotetext{
${ }^{1}$ One possible limitation to our approach is that the GHG benefits of wind may be eroded to a degree by the increased cycling, ramping, and part loading required of natural gas and coal generators. Though our analysis does not capture these effects, previous work has shown that this erosion is small in large electric systems (Fripp 2011; Valentino et al. 2012). Recent studies have found that the GHG benefits of wind are diminished by, at most, less than 10\% (Göransson and Johnsson 2009; Gross et al. 2006; Pehnt et al. 2008; Perez-Arriaga and Batlle 2012). In the most sophisticated of these studies, Lew et al. (2013) find that the emissions impact is negligible (less than 1\%).
} 
Though this has led some to suggest possible improvements to SCC estimates (Ackerman and Stanton 2012; Arrow et al. 2013; Johnson and Hope 2012; Kopp et al. 2012) or even to question the use of these estimates (Pindyck 2013), U.S. government regulatory bodies now regularly use SCC estimates when formulating policy (GAO 2014; Kopp and Mignone 2012).

To support U.S. agencies, the U.S. Interagency Working Group on the Social Cost of Carbon (IWG) has used three integrated assessment models to estimate the SCC (IWG 2010; IWG 2013). The IWG SCC estimates reflect global damages from GHGs, as recommended by the IWG for use in regulatory decisions. To reflect the inherent uncertainties, IWG (2013) includes four distinct SCC trajectories. Three are based on the expected value of the SCC (estimated by averaging the results of the three integrated assessment models) assuming different discount rates of $2.5 \%, 3 \%$, and $5 \%$. The fourth trajectory represents a 95th percentile of the SCC estimates across all three models at the central $3 \%$ social discount rate. This 95th-percentile case is intended to reflect a much less likely outcome with a much higher than expected impact. The four trajectories cover a wide range, with the SCC in the lowest case increasing from $\$ 12 /$ metric tonne of $\mathrm{CO}_{2}$ in 2012 to $\$ 29 /$ metric tonne in 2050 and in the highest case increasing from $\$ 108 /$ metric tonne to $\$ 246 /$ metric tonne. In the IWG's "central value" case (expected value, 3\% discount rate), the SCC increases from $\$ 38 /$ metric tonne to $\$ 79 /$ metric tonne. These SCC estimates have been widely used in regulatory impact analyses (GAO 2014). We present results based on all four IWG SCC trajectories.

\subsection{Results}

Meeting the wind deployment levels of the Study Scenario will reduce fossil energy use and carbon emissions. Figure 1 highlights the annual and cumulative lifecycle emissions for the Study Scenario relative to the no-new-wind Baseline Scenario: 6\% lower electric-sector GHG emissions in 2020, 16\% in 2030 , and $23 \%$ in 2050 , with cumulative GHG emissions reduced by 12.3 billion metric tonnes of carbon dioxide equivalent $\left(\mathrm{CO}_{2} \mathrm{e}\right)$ from 2013 to 2050 (14\%). These estimates suggest significant potential for wind to reduce GHGs, which is consistent with previous literature (DOE 2008; Wiser et al. 2011). 


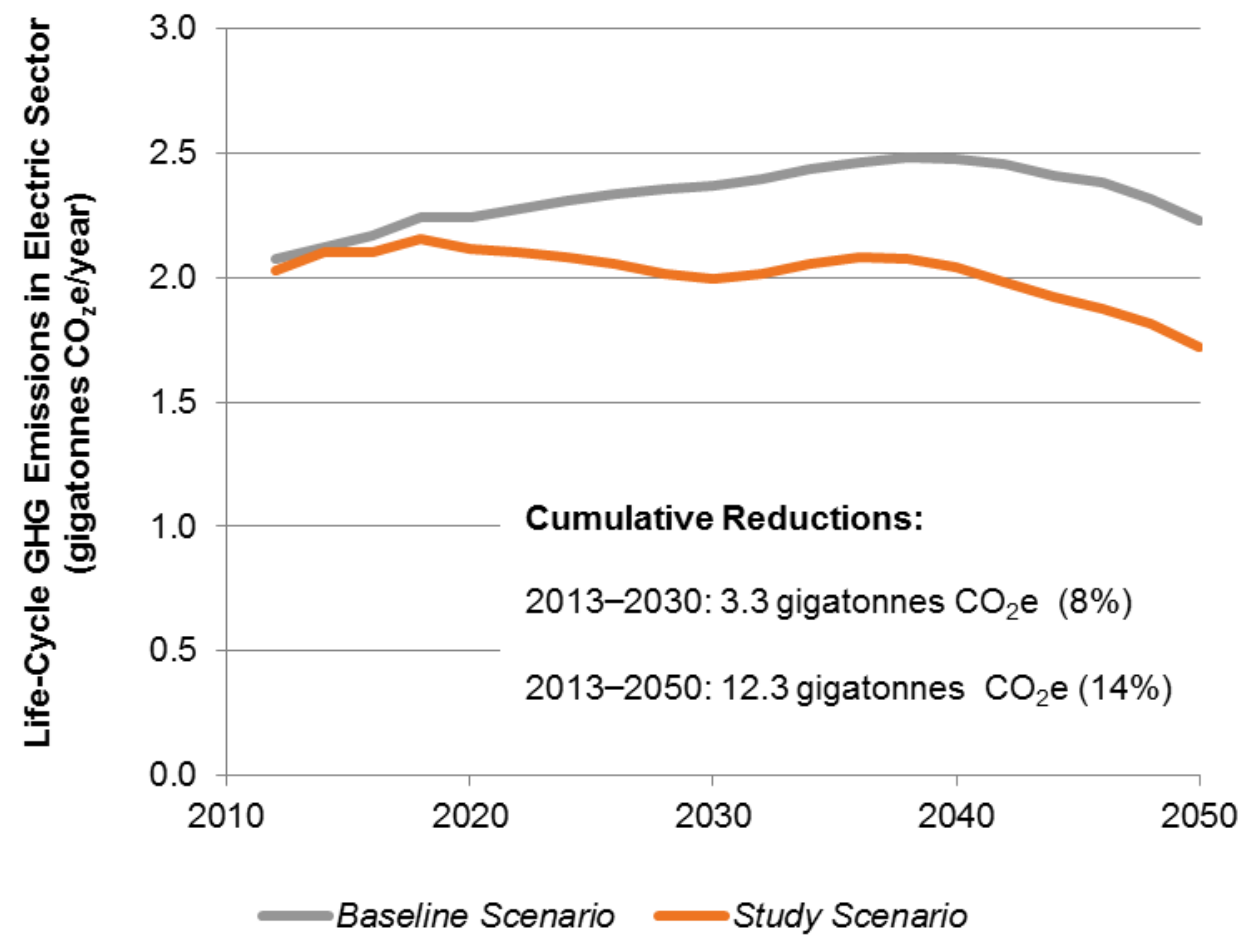

Figure 1. Electric-sector lifecycle GHG emissions in the Study and Baseline Scenarios

Figure 2 applies the four IWG SCC trajectories to show the global GHG-reduction benefits from 2013 to 2050 of the Study Scenario compared to the no-new-wind Baseline Scenario. For the central value case, estimated discounted, present-value benefits are roughly $\$ 400$ billion. Across the three expected-value cases, benefits range from $\$ 85$ billion to $\$ 640$ billion. The fourth case, which accounts for the smaller possibility of more-extreme effects, results in a benefit estimate of $\$ 1,230$ billion. The central-value estimate represents a levelized global benefit of wind energy of $3.2 \mathrm{c} / \mathrm{kWh}$-wind.

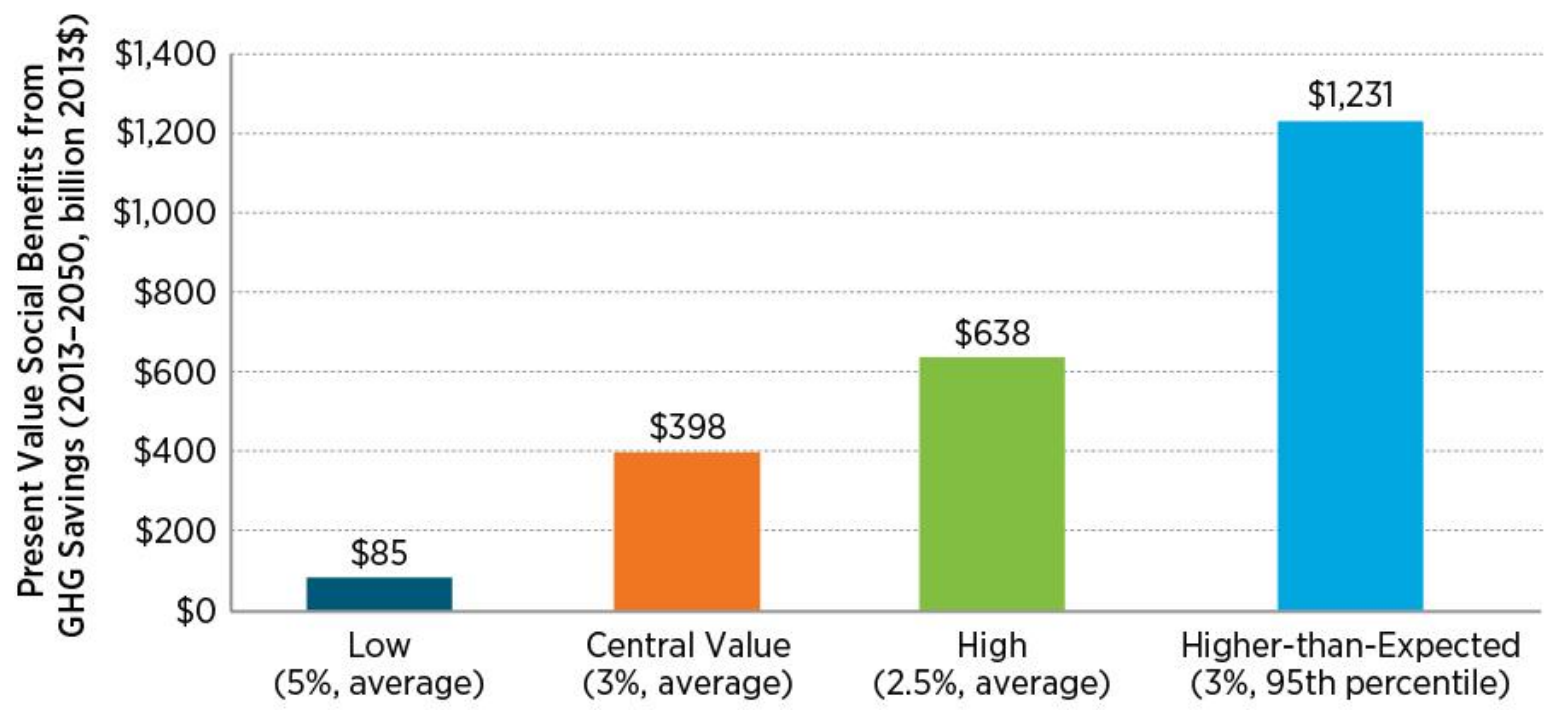

Figure 2. Estimated benefits of the Study Scenario due to reduced global climate-change damages 


\section{Air-Pollution Impacts}

\subsection{Overview}

Beyond GHG reductions, expanded use of wind energy could produce health, environmental, and ecosystem impacts related to air pollutants, water pollutants, land use and degradation, and waste generation and disposal (Cleveland et al. 2004; IPCC 2011; Masanet et al. 2013; NRC 2010). Of these, air pollution is among the most important because of the significant costs to society of these emissions (IPCC 2011).

On a lifecycle basis, air-pollutant emissions from wind are much lower than from fossil-fuel-based generation (IPCC 2011; Turconi et al. 2013). Several major studies have estimated the monetary damages associated with air pollution from different electric-generation sources (European Commission 2003; Krewitt and Schlomann 2006; Preiss 2009; Ricci 2010), demonstrating that health-related externalities are much lower for wind than for almost all other technologies. The National Research Council (NRC 2010) estimated U.S. damages due to particulate matter (PM) [both coarse particles (PM10) and fine particles $\left(\mathrm{PM}_{2.5}\right)$ ], sulfur dioxide $\left(\mathrm{SO}_{2}\right)$, and oxides of nitrogen $\left(\mathrm{NO}_{\mathrm{x}}\right)$. It found that the monetized adverse effects from these emissions were primarily due to human health but also included consequences from decreased timber and agriculture yields, reduced visibility, accelerated degradation of materials, and reductions in recreation services. Coal power plants were found to be the dominant source of damages. Various recent studies have shown even larger estimated impacts (Driscoll et al. 2015; EPA 2014; Fann et al. 2009, 2012; Machol and Rizk 2013; Muller et al. 2011; Shindell 2015; Thompson et al. 2014).

\subsection{Methods}

This section first estimates the potential air-pollution reductions from the Study Scenario compared to the no-new-wind Baseline. It then assesses the associated health and environmental benefits, using two different methods and developing three different monetary estimates. In all cases, only a subset of wind's potential air-pollution benefits are evaluated, focused on $\mathrm{SO}_{2}, \mathrm{NO}_{x}$, and $\mathrm{PM}_{2.5}$. The basic methods applied here are broadly consistent with those used in the broader literature (Cullen 2013; Heeter et al. 2014; Johnson et al. 2013; Siler-Evans et al. 2013; McCubbin and Sovacool 2013; Novan 2014).

We developed pollutant-emission estimates for the Study and no-new-wind Baseline Scenarios on a regional basis. They are a function of the product of ReEDS generation outputs (megawatt-hours, by generation type and vintage) and assumed emission rates (grams per megawatt-hour, by generation type and vintage). The stringency of future air-pollution regulations impacts emissions rates (and generation investment and dispatch decisions) and therefore affects estimates of the benefits of wind energy. We estimated emission rates for 2012 based on reported historical plant-level emission rates, and we aggregated them to each type of power plant in ReEDS and to each of the ReEDS regions. Emission rates were then revised over time as plants retired and as the Mercury and Air Toxics Standards (MATS) and Cross-States Air Pollution Rule (CSAPR) are presumed to take effect. ${ }^{2}$

\footnotetext{
${ }^{2}$ Increased reliance on wind will require fossil plants to operate in a more flexible manner, potentially creating an emissions penalty (Denny and O'Malley 2006; Kaffine et al. 2013). Though our analysis does not fully capture these effects, results from recent research suggest that emissions are reduced by wind energy, even after accounting for any emissions penalties (GE Energy Consulting 2014; Oates and Jaramillo 2013; Valentino et al. 2012). In a recent and thorough analysis, Lew et al. (2013) find that accounting for impacts related to increased coal plant cycling slightly improves (by $1 \%-2 \%$ ) the avoided $\mathrm{NO}_{\mathrm{x}}$ emissions of wind and solar relative to the avoided emissions based
} 
Translating emission reductions into monetized health-damage reductions depends on the atmospheric dispersion and secondary reaction of those pollutants, population exposure to primary and secondary pollutants, the exposure-response relationship for specific health outcomes, and the monetary quantification of those outcomes. For these steps, we use two different approaches to estimate benefits under three scenarios, capturing at least a subset of the associated uncertainties.

First, we use methods applied by the U.S. Environmental Protection Agency (EPA), most recently for the Clean Power Plan (EPA 2014). EPA (2014) has established two different sets of estimates for the average benefit per ton of reduced $\mathrm{SO}_{2}, \mathrm{NO}_{x}$, and $\mathrm{PM}_{2.5}$ emissions across three broad U.S. regions, resulting in an "EPA-low" and an "EPA-high" estimate of the Study Scenario benefits. The range between EPA-low and EPA-high is entirely due to uncertainty in the epidemiology that connects pollution exposure to health consequences. EPA-low is based on research summarized in Krewski et al. (2009) and Bell et al. (2004), whereas EPA-high is based on research presented in Lepeule et al. (2012) and Levy et al. (2005). Second, we use benefit-per-ton estimates from the Air Pollution Emission Experiments and Policy analysis model version 2 (AP2), also for $\mathrm{SO}_{2}, \mathrm{NO}_{x}$, and $\mathrm{PM}_{2.5}$. AP2 relies on epidemiology assumptions consistent with EPA-low, but it applies different air-quality and meteorological modeling techniques, which, in part, drive lower benefit estimates. Unlike the EPA methods applied here-which distinguish damage factors only among three large U.S. regions-AP2 varies damage factors on a more refined, county-level basis. An earlier version of this model was used by NRC (2010), and Siler-Evans et al. (2013) to estimate the benefits of wind. Details of the differences between this model and the EPA methods are highlighted in Brown et al. (2013), DOE (2015), Fann et al. (2012), and Machol and Rizk (2013), while further details on all our air-pollution benefit-estimation methods can be found in DOE (2015).

DOE (2015) also discusses an alternate approach to quantifying air-pollution benefits, which assumes the presence of binding cap-and-trade programs that limit air pollution. Under strictly binding cap-andtrade programs, increased wind energy may not reduce capped pollution emissions because the potential avoided emissions from wind may be offset by increases in emissions elsewhere as allowed under the cap (Cullen 2013; Siler-Evans et al. 2013). In this instance, the benefits of wind energy derive not from reduced health and environmental damages but instead from reducing the cost of complying with the air-pollution regulations. Though cap-and-trade programs currently exist in various U.S. regions for both $\mathrm{SO}_{2}$ and $\mathrm{NO}_{x}$, those programs have not been fully binding in recent years (EPA 2013; Schmalensee and Stavins 2013). Moreover, our assessment of the Study and Baseline Scenarios suggests that the CSAPR caps are unlikely to be strongly binding in the presence of MATS. We therefore do not estimate the benefits of the Study Scenario from the perspective of reducing pollution regulation compliance costs. Nonetheless, we mention this alternative valuation approach because it is possible that future cap-and-trade regulations applied either nationally or regionally could impact the size and nature of the benefits from the Study Scenario.

\subsection{Results}

Achieving the Study Scenario reduces national $\mathrm{SO}_{2}, \mathrm{NO}_{x}$, and $\mathrm{PM}_{2.5}$ emissions relative to the no-newwind Baseline Scenario in which no additional wind-capacity growth occurs (Figure 3). Cumulatively, the Study Scenario has estimated emission reductions from 2013 to 2050 (relative to the Baseline Scenario)

on an assumption of a fully loaded plant, but that accounting for cycling impacts reduces the avoided $\mathrm{SO}_{2}$ emissions of wind and solar by 3\%-6\%. A similarly detailed analysis of avoided $\mathrm{NO}_{x}$ and $\mathrm{SO}_{2}$ emissions with wind and solar in the mid-Atlantic region reports more substantial emissions penalties (GE Energy Consulting 2014). In both cases, however, the impacts are not large enough to alter dramatically the basic results reported here. 
of 2.6 million metric tonnes of $\mathrm{SO}_{2}, 4.7$ million metric tonnes of $\mathrm{NO}_{x}$, and 0.5 million metric tonnes of $\mathrm{PM}_{2.5}$.
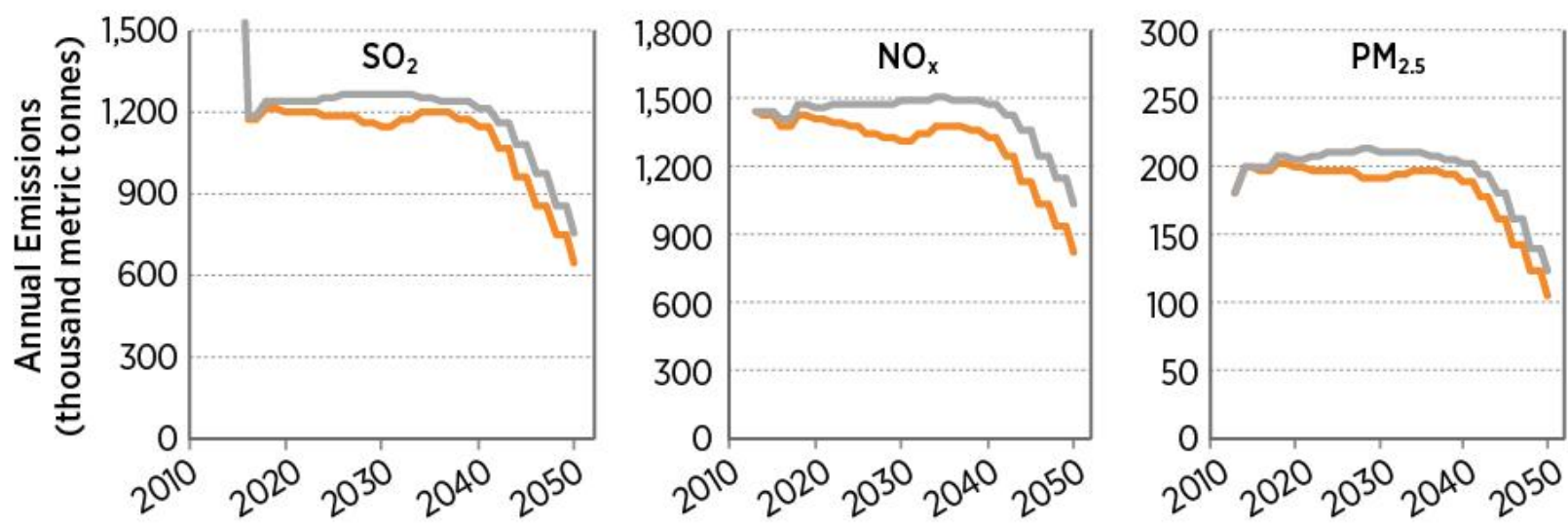

- Baseline Scenario - Study Scenario

Figure 3. Electric-sector $\mathrm{SO}_{2}, \mathrm{NO}_{x}$, and $\mathrm{PM}_{2.5}$ emissions in Study and Baseline Scenarios

Based on these reductions, Figure 4 summarizes the estimated air-pollution benefits of the Study Scenario (relative to the no-new-wind Baseline) on a national basis. Discounted, present-value benefits are estimated at $\$ 52$ billion, \$108 billion, and \$272 billion under AP2, EPA-low, and EPA-high, respectively (3\% discount rate, 2013-2050), equivalent to an average levelized benefit of $0.4 \mathrm{C} / \mathrm{kWh}$ wind, $0.9 \mathrm{c} / \mathrm{kWh}$-wind, and $2.2 \mathrm{c} / \mathrm{kWh}$-wind.

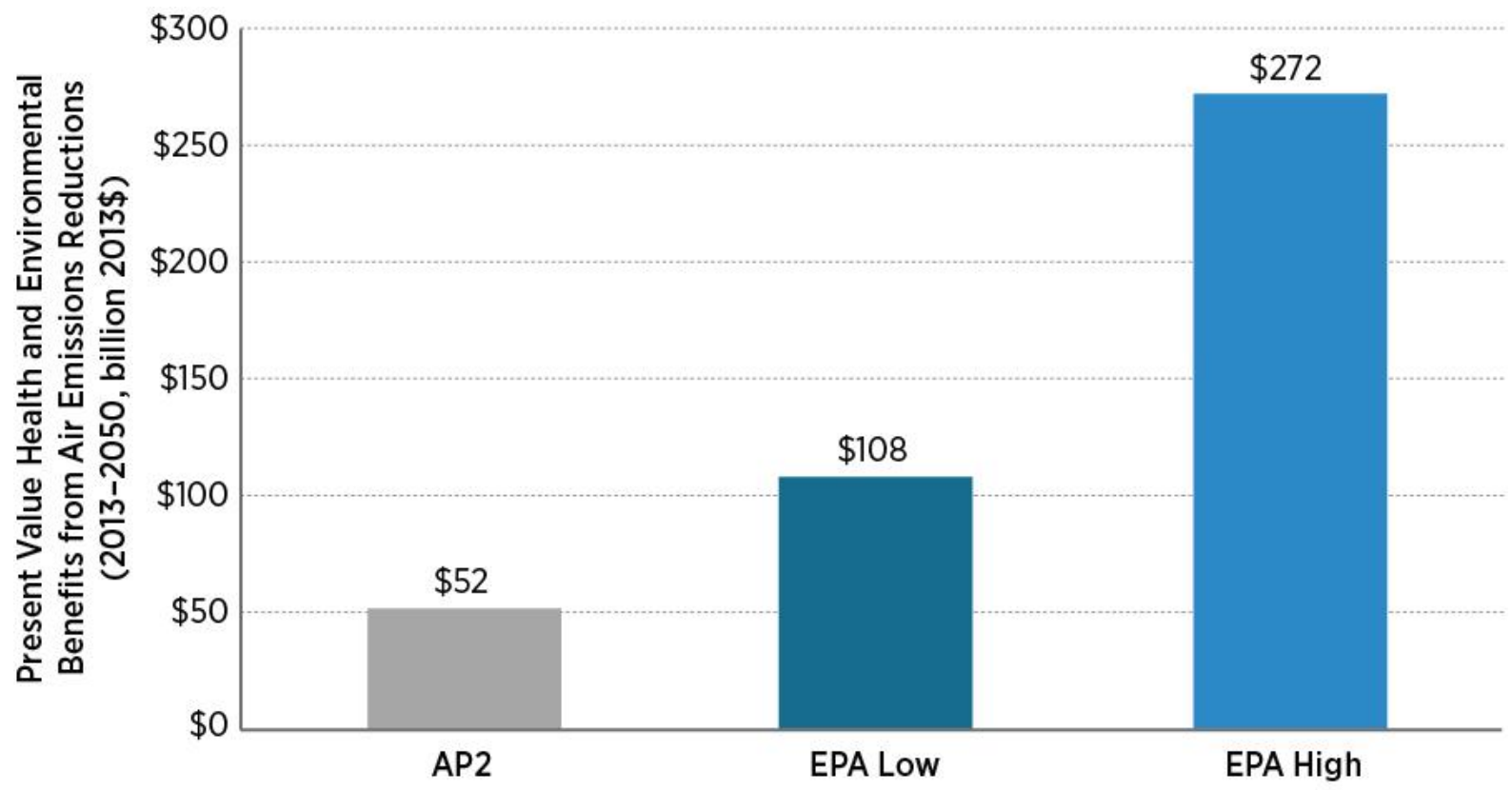

Figure 4. Estimated benefits of the Study Scenario due to reduced $\mathrm{SO}_{2}, \mathrm{NO}_{x}$, and $\mathrm{PM}_{2.5}$ emissions

Table 2 provides additional detail on these estimates. Overall, most of the monetary benefits derive from reduced levels of premature mortality. Focusing on the EPA-low case, because it is in the middle of the range of estimates presented here, the Study Scenario results in nearly 22,000 fewer premature 
mortalities than the Baseline Scenario over the 2013-2050 timeframe. While representing a smaller monetary benefit, a large number of additional morbidity benefits are estimated, from fewer visits to the hospital due to cardiovascular, respiratory, or asthma symptoms to fewer lost work days. Under the EPA-low case, $66 \%$ of the benefits are derived from reduced $\mathrm{SO}_{2}$ emissions. $\mathrm{SO}_{2}$ is transformed in the atmosphere to sulfate $\mathrm{PM}$, with significant health consequences. Reduced $\mathrm{NO}_{\mathrm{x}}$ emissions account for $26 \%$ of the benefits in the EPA-low case, primarily owing to the transformation of $\mathrm{NO}_{\mathrm{x}}$ in the atmosphere to nitrate $\mathrm{PM}$ and, to a lesser extent, from the influence of $\mathrm{NO}_{\mathrm{x}}$ in promoting ozone production. Reduced direct $\mathrm{PM}_{2.5}$ emissions account for $8 \%$ of the benefits. A large majority $(>95 \%)$ of the health benefits concentrate in the eastern half of the United States, especially where air pollution from coal plants predominates.

Table 2. Accumulated Air Pollution Benefits over 2013 - 2050 for the Study Scenario Relative to the Baseline Scenario

\begin{tabular}{|c|c|c|c|c|c|}
\hline & & $\mathrm{SO}_{2}$ & $\mathrm{NO}_{x}$ & $\mathrm{PM}_{2.5}$ & Total \\
\hline Wind Vision & & \multicolumn{3}{|c|}{ Emissions reductions } & \\
\hline \multirow[t]{2}{*}{ Reductions } & (millions metric tons) & 2.6 & 4.7 & 0.5 & --- \\
\hline & \multicolumn{5}{|c|}{ Total monetized benefits (present value) } \\
\hline \multirow[t]{2}{*}{ EPA Benefits } & EPA Low (Billions 2013\$) & 71 & 28 & 9 & 108 \\
\hline & EPA High (Billions 2013\$) & 174 & 78 & 21 & 272 \\
\hline AP2 Benefits & AP2 (Billions 2013\$) & 24 & 19 & 8 & 52 \\
\hline EPA & \multicolumn{5}{|c|}{ Total mortality reductions } \\
\hline Mortality & EPA Low & 14,400 & 5,500 & 1,900 & 21,700 \\
\hline Benefits & EPA High & 29,100 & 15,200 & 4,300 & 48,700 \\
\hline EPA & \multicolumn{5}{|c|}{ Morbidity reductions from primary and secondary $\mathrm{PM}_{2.5}$ effects } \\
\hline $\begin{array}{l}\text { Morbidity } \\
\text { Benefits }\end{array}$ & Emergency department visits for asthma (all ages) & 7,000 & 2,200 & 900 & 10,100 \\
\hline \multirow{12}{*}{ Benefits } & Acute bronchitis (age 8-12) & 18,800 & 5,500 & 2,500 & 26,800 \\
\hline & Lower respiratory symptoms (age 7-14) & 242,200 & 69,900 & 31,900 & 344,000 \\
\hline & Upper respiratory symptoms (asthmatics age 9-11) & 383,000 & 111,600 & 45,600 & 540,200 \\
\hline & Minor restricted-activity days (age 18-65) & $9,118,000$ & $2,685,800$ & $1,243,000$ & $13,046,600$ \\
\hline & Lost work days (age 18-65) & $1,525,800$ & 462,900 & $2,040,008$ & $2,192,700$ \\
\hline & Asthma exacerbation (age 6-18) & 858,800 & 104,300 & 47,700 & $1,010,800$ \\
\hline & Hospital Admissions-Respiratory (all ages) & 5,000 & 1,400 & 600 & 7,000 \\
\hline & Hospital Admissions-Cardiovascular (age $>18$ ) & 5,400 & 1,800 & 700 & 7,900 \\
\hline & Non-fatal Heart Attacks (Peters et al 2001) & 17,700 & 5,400 & 2,300 & 25,300 \\
\hline & Non-fatal Heart Attacks (Pooled estimates - 4 studies) & 2,000 & 600 & 200 & 2,800 \\
\hline & \multicolumn{5}{|c|}{ Morbidity reductions from $\mathrm{NO}_{x} \rightarrow$ Ozone effects } \\
\hline & Hospital Admissions, Respiratory (ages > 65) & --- & 9,200 & --- & 9,200 \\
\hline
\end{tabular}




\begin{tabular}{rrrrr} 
Hospital Admissions, Respiratory (ages < 2) & --- & 2,800 & --- & 2,800 \\
Emergency Room Visits, Respiratory (all ages) & --- & 3,800 & --- & 3,800 \\
Acute Respiratory Symptoms (ages 18-65) & --- & $5,882,000$ & --- & $5,882,000$ \\
School Loss Days & --- & $2,459,600$ & --- & $2,459,600$ \\
\hline
\end{tabular}

Notes: Monetized benefits are discounted at 3\%, but mortality and morbidity values are simply accumulated over the 20132050 time period. EPA benefits derive from mortality and morbidity estimates based on population exposure to direct emissions of PM2.5 and secondary PM2.5 (from SO2, NOx emissions) as well as ozone exposure from NOx emissions during the ozone season (May - September). Primary and secondary PM2.5 effects account for $~ 90 \%$ of the mortalities and monetized benefits in both the high and low cases. AP2 benefits derive from mortality and morbidity estimates based on population exposure to direct emissions of PM2.5, SO2 and NOx, secondary PM2.5 (from SO2, NOx emissions) as well as ozone exposure from NOx emissions during the ozone season (May - September). AP2 benefits also include consequences from decreased timber and agriculture yields, reduced visibility, accelerated degradation of materials, and reductions in recreation services.

\section{Water Use Reduction}

\subsection{Overview}

Water use has two key metrics: withdrawal and consumption. Withdrawal is the amount of water removed from the ground or diverted from a water source for use but then returned to the source, often at a higher temperature. Consumption is the amount of water evaporated, transpired, incorporated into products or crops, or otherwise removed from the immediate water environment. The primary water demands for the electric sector-both withdrawal and consumption-are for thermalplant cooling.

The electric sector is the largest withdrawer of freshwater in the United States. It accounted for $41 \%$ of all withdrawals in 2005 (Kenny et al. 2009). Freshwater consumption from the electric sector, meanwhile, represents a much smaller fraction of the national total (3\%) but can be regionally important (Averyt et al. 2013; Solley et al. 1998). As a result, the sector both impacts and is highly dependent on water resources (Chandel et al. 2011; Macknick et al. 2012a; Sáenz de Miera et al. 2012; Tidwell et al. 2013; van Vliet et al. 2012). At times power plants have been forced to curtail generation owing to water-related restrictions (Averyt et al. 2011; DOE 2013). Water availability may also influence the future development of the electric sector, affecting what types of power plants and cooling systems are built and where those plants are sited (Averyt et al. 2011). These vulnerabilities may be exacerbated by future changes in the climate (DOE 2013; Melillo et al. 2014).

Operational water use can vary greatly depending on the type of fuel, power plant, and cooling system, and wind power requires the lowest amount of water consumption and withdrawal among all generation types (Macknick et al. 2012a). Thus, wind energy could reduce water impacts and waterrelated vulnerabilities, potentially providing economic and environmental benefits.

\subsection{Methods}

This section evaluates the potential operational water withdrawal and consumption reductions associated with the Study Scenario compared to the no-new-wind Baseline on a national level. Because water resources are managed locally and water is not easily transferred across basins, the analysis also focuses on 18 defined watershed regions in the contiguous United States. Finally, the potential economic and environmental benefits of water-use reductions are explored.

In addition to water required for plant operations, water may also be needed in the fuel cycle, equipment manufacturing, and construction (Fthenakis and Kim 2010; Meldrum et al. 2013). On a 
lifecycle basis, thermoelectric water withdrawals and consumption during plant operations are orders of magnitude greater than these other demands (Meldrum et al. 2013); as such, this section focuses on operational water requirements. However, as discussed in Averyt et al. (2011), the additional fuel-cycle water demands can have important water-quality implications due to, for example, water used in mining, coal washing, and hydraulic fracturing. These negative water-use implications of fossil generation might also be partly avoided by increased use of wind energy.

We used ReEDS to compute, on a national and regional basis, electric-sector water withdrawal and consumption in both the Study and no-new-wind Baseline Scenarios. Water impacts were aggregated from the ReEDS model regions to the 18 U.S. Geological Survey Hydrologic Unit Code watershed regions (Seaber et al. 1987). Data aggregation techniques follow those described in Macknick et al. (2012b) and Sattler et al. (2012). ReEDS incorporates the cost, performance, and water-use characteristics of different generation fuel-technology and cooling-system combinations, and it considers water availability as a condition for new power-plant construction. Cooling systems implemented in ReEDS fall into four categories: once-through, pond, recirculating, and dry-cooling systems. Power-plant fuel sources, cooling types, and locations are endogenously determined within the model, considering water-use costs and constraints.

Water use will be impacted by various changes in the electric sector, such as coal-plant retirements, new combined-cycle natural gas plant construction, and the increased use of dry cooling. These changes, in turn, may be driven in part by future water policies, and they could affect the estimated water savings under the Study Scenario. Consistent with prior studies and proposed EPA regulations, our analysis does not allow new power plants in ReEDS to employ once-through cooling technologies (Macknick et al. 2012b; Tidwell et al. 2013).

\subsection{Results}

Meeting the wind-deployment levels of the Study Scenario reduces national electric-sector water use, both compared with recent use and compared with the no-new-wind Baseline Scenario (Figure 5). Withdrawals decline substantially over time under both the Study and Baseline Scenarios. This is largely due to the retirement and reduced operations of once-through-cooled facilities and the assumed replacement of those plants with newer, less-water-intensive generation and cooling technologies. Because of this, all but one of the 18 major watershed regions experiences reductions in withdrawals in the Baseline Scenario from 2012 to 2050, and all regions experience reductions in the Study Scenario. The Study Scenario drives greater reductions overall, however, with national electric-sector water withdrawals declining by $1 \%$ in $2020,4 \%$ in 2030 , and $15 \%$ in 2050 , relative to the Baseline.

Unlike withdrawals, national electric-sector water consumption remains higher than 2012 consumption until after 2040 under the Baseline Scenario, after which it declines. Water consumption decreases sooner and more significantly in the Study Scenario. The delayed decrease in water consumption in the Baseline Scenario is caused by the assumed replacement of once-through-cooled plants with those using recirculating cooling systems that consume more water per unit of electricity production. Such cooling system changes also occur in the Study Scenario, but the greater penetration of wind energy reduces water consumption for the sector as a whole. Overall, national electric-sector water consumption declines by $4 \%$ in 2020, 11\% in 2030, and 23\% in 2050 in the Study Scenario relative to the Baseline Scenario. 


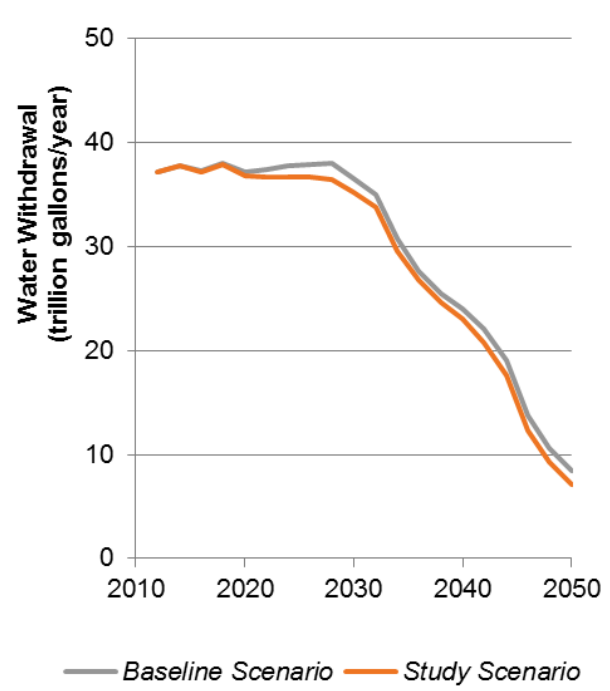

(a)

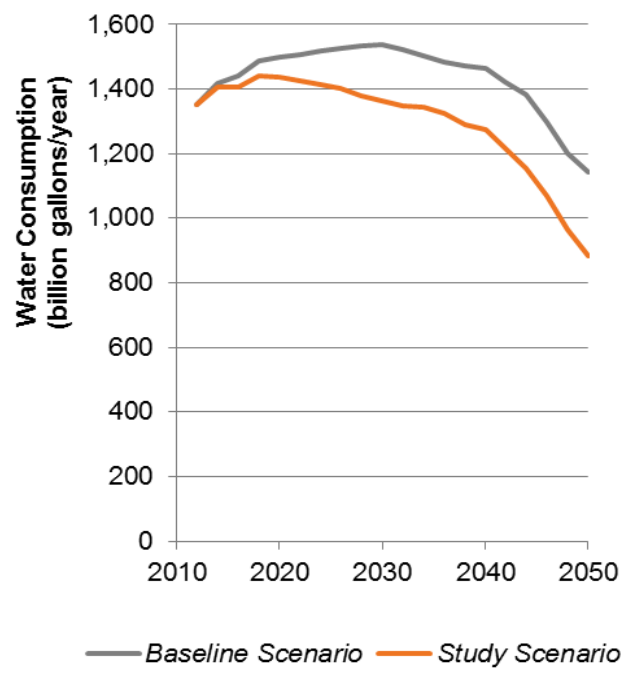

(b)

Figure 5. Electric-sector water withdrawals (a) and consumption (b) for the Study and Baseline Scenarios

Water consumption declines by 2050 in all but two of the 18 watershed regions under the Study Scenario ${ }^{3}$; in 11 of 18 regions, consumption reductions are greater than $30 \%$ (Figure 6). In the no-newwind Baseline Scenario, five regions experience an increase in consumption by 2050. Consumption increases in additional watershed regions covering parts of water-stressed states such as Texas, Oklahoma, New Mexico, Nevada, Utah, and Colorado. Though the electric sector is not a major water consumer nationally, the large potential increases in electric-sector water consumption under the Baseline Scenario in arid states-which, in many cases, already experience water-availability issuescould increase regional competition for water resources.

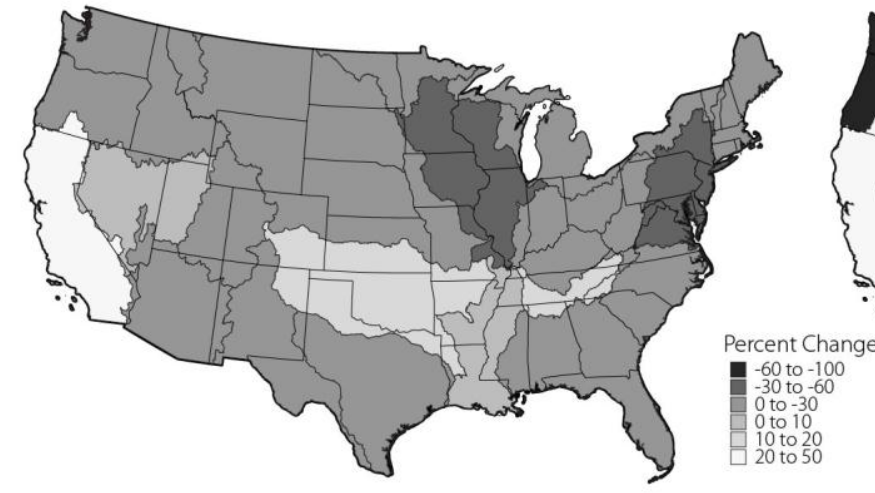

(a) Baseline Scenario (2012-2050)

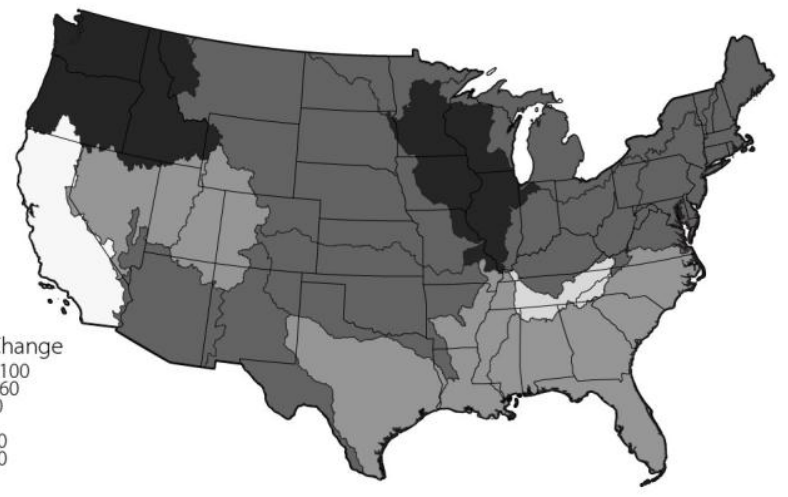

(b) Study Scenario (2012-2050)

Figure 6. Percentage change in water consumption in 2050 compared with 2012 for the Baseline (a) and Study (b) Scenarios

\footnotetext{
${ }^{3}$ Regional increases under the Study Scenario occur in portions of the Southeast and in California. In the Southeast, high-withdrawal and low-consumption cooling technologies for thermal power plants are assumed to be replaced by low-withdrawal and high-consumption cooling, and wind penetration is lower than in other regions. In California, increases in consumption are largely a result of additional natural gas plants with recirculating cooling.
} 
The ability of wind energy to reduce water withdrawals and consumption may offer societal benefits, especially where water is scarce. Increased wind energy reduces the vulnerability of electricity supply to the availability or temperature of water, potentially avoiding electric-sector reliability events and/or the effects of reduced thermal plant efficiencies. These concerns might otherwise grow as the climate changes (DOE 2013). Additionally, increased wind deployment might help make water available, which could then be used for other productive purposes (e.g., agricultural, industrial, or municipal use) or to strengthen local ecosystems (e.g., benefiting wildlife owing to greater water availability, lack of temperature change, etc.). The lower lifecycle water requirements of wind energy, meanwhile, may help alleviate other energy-sector impacts on water resource quality and quantity, e.g., water otherwise used in mining, coal washing, and hydraulic fracturing (Averyt et al. 2011). Finally, wind deployment might help reduce the cost of future policies intended to limit water use.

The ReEDS model includes the characteristics of different cooling technologies as well as the availability and cost of water supply in its optimization. Quantifying any separable, additional benefit from the water-use reductions is difficult, because no standardized methodology exists to do so. One way to judge the potential economic benefit of water savings is to consider wind deployment as avoiding the possible need to employ thermal power plants with lower water use or to site power plants where water is available and less costly. To an extent, these costs are already embedded in the ReEDS results. However, water could become scarcer in the future, and/or water policy could become stricter, necessitating additional investments. In such an instance, a possible upper limit on the incremental cost of water associated with thermal generation can be estimated by comparing the cost of traditional wet cooling with the cost of dry cooling. The total cost increase of dry cooling for coal generation has been estimated at 0.32-0.64 $\mathrm{c} / \mathrm{kWh}$ (Zhai and Rubin 2010). For natural gas combined-cycle plants, Maulbetsch and DiFilippo (2006) estimate an "effective cost" of saved water that corresponds to approximately $0.06-0.17 \mathrm{c} / \mathrm{kWh}$. These estimated incremental costs for dry cooling are relatively small, and they likely set an upper limit on the water-related benefits of wind energy or any other power technology intended, in part, to reduce water use.

\section{Other Impacts: Energy Diversity and Risk Reduction, Workforce and Economic Development, and Land Use and Local Impacts}

The Wind Vision report (DOE 2015) also addresses impacts associated with energy diversity and risk reduction, workforce and economic development, and land-use and local impacts. Unlike the previously addressed environmental benefits (and the costs discussed in DOE (2015) and Lantz et al. forthcoming), however, we emphasize that these additional considerations might best be termed "impacts." This is because they-to a degree-represent resource transfers, and we do not attempt here to assess the "net" social welfare impact of those transfers. Because of that, we highlight key results here without fully describing them or the underlying methods; see DOE (2015) for further details.

\subsection{Energy Diversity and Risk Reduction}

Though wind energy is not free of risk, it relies on a domestic "fuel" stream not subject to significant resource exhaustion or price uncertainty. Various methods have been used to assess the benefits of these characteristics as well as the benefits of electricity supply diversity more generally. These methods have included the use of risk-adjusted discount rates (Awerbuch 1993), Monte Carlo and decision analysis (Wiser and Bolinger 2006), mean variance-based portfolio theory (Awerbuch and Berger 2003; Bazilian and Roques 2008), market-based assessments of the cost of conventional fuel-price hedges (Bolinger et al. 2006), various diversity indices (Stirling 1994; Stirling 2010), comparisons of empirical 
wind contract prices to gas price forecasts (Bolinger 2013), and estimates of a generation portfolio's sensitivity to high and low fuel prices under high-renewable-penetration scenarios (Jenkin et al. 2013). Many of these methods have proven to be incomplete or even controversial, thus a single, standard approach to benefit quantification has not emerged.

While a full suite of standardized tools for quantifying the myriad risks associated with different electricity-resource portfolios is not available, wind energy can reduce certain risks. In particular, an increase in wind generation mitigates long-term fossil fuel price risks in two ways that can be quantified using recognized and-with appropriate caveats-accepted methods. First, by providing electricity purchasers with a long-term fixed-price source of supply, wind can directly offset the use of fuel streams with variable and uncertain prices, thereby potentially reducing uncertainty in future electric-system costs. Second, by reducing demand for fossil fuels, wind can place downward pressure on fossil fuel prices, with benefits to energy consumers both within and outside of the electricity sector.

As described more fully in DOE (2015), we evaluate both effects and find that the Study Scenario contributes to a reduction in both long-term natural gas price risk and natural gas prices, compared to the no-new-wind Baseline Scenario. Following Jenkin et al. (2013), we find that replacing coal and natural gas generation with wind under the Study Scenario results in total electric-system costs that are $20 \%$ less sensitive to long-term fluctuations in fossil fuel prices than under the Baseline Scenario. Following Wiser and Bolinger (2007), we find that the Study Scenario reduces natural gas demand, suppressing gas prices and potentially leading to $\$ 280$ billion in consumer savings (present value, 20132050) outside the electric sector. To be clear, we make no claim of a net societal gain from these impacts: the reduced sensitivity of electric-system costs to fluctuations in fossil prices is only a benefit in the presence of risk-averse end-use customers, while the consumer savings associated with reduced natural gas prices comes at the expense of natural gas producers.

\subsection{Workforce and Economic Development}

The impacts of wind-related manufacturing and deployment on jobs and other indicators of local economic development have been analyzed previously using a variety of methods (e.g., Brown et al. 2012; DOE 2008; Druckenmiller 2012; GAO 2004; Lantz and Tegen 2008; Pedden 2006; Wei et al. 2010). To assess the potential gross wind-related employment and economic-development impacts of the Study Scenario, we used NREL's Jobs and Economic Development Impacts (JEDI) model. JEDI is an inputoutput-based model and has been used extensively in national (e.g., DOE 2008; Navigant 2013; Steinberg et al. 2012) and local (e.g., Flores et al. 2014; Keyser et al. 2014; Lantz and Tegen 2008; Loomis and Carter 2011; Slattery et al. 2011) wind assessments. Because impacts will be dictated, in part, by the degree to which wind equipment is manufactured in the United States, a range of potential labor-force needs is quantified: one with an assumed lower level of domestic content and one with a higher level.

We find that the Study Scenario can support a U.S. wind industry that grows from roughly 100,000 fulltime-equivalent jobs today (inclusive of onsite, supply-chain, and induced jobs) to $201,000-265,000$ in 2020 and then to $526,000-670,000$ in 2050 (Figure 7). Wind additions are also found to support landbased lease payments that grow to $\$ 1$ billion in 2050, offshore-wind lease payments that reach $\$ 440$ million in 2050, and wind-project property tax payments that increase to \$3.2 billion in 2050 . 

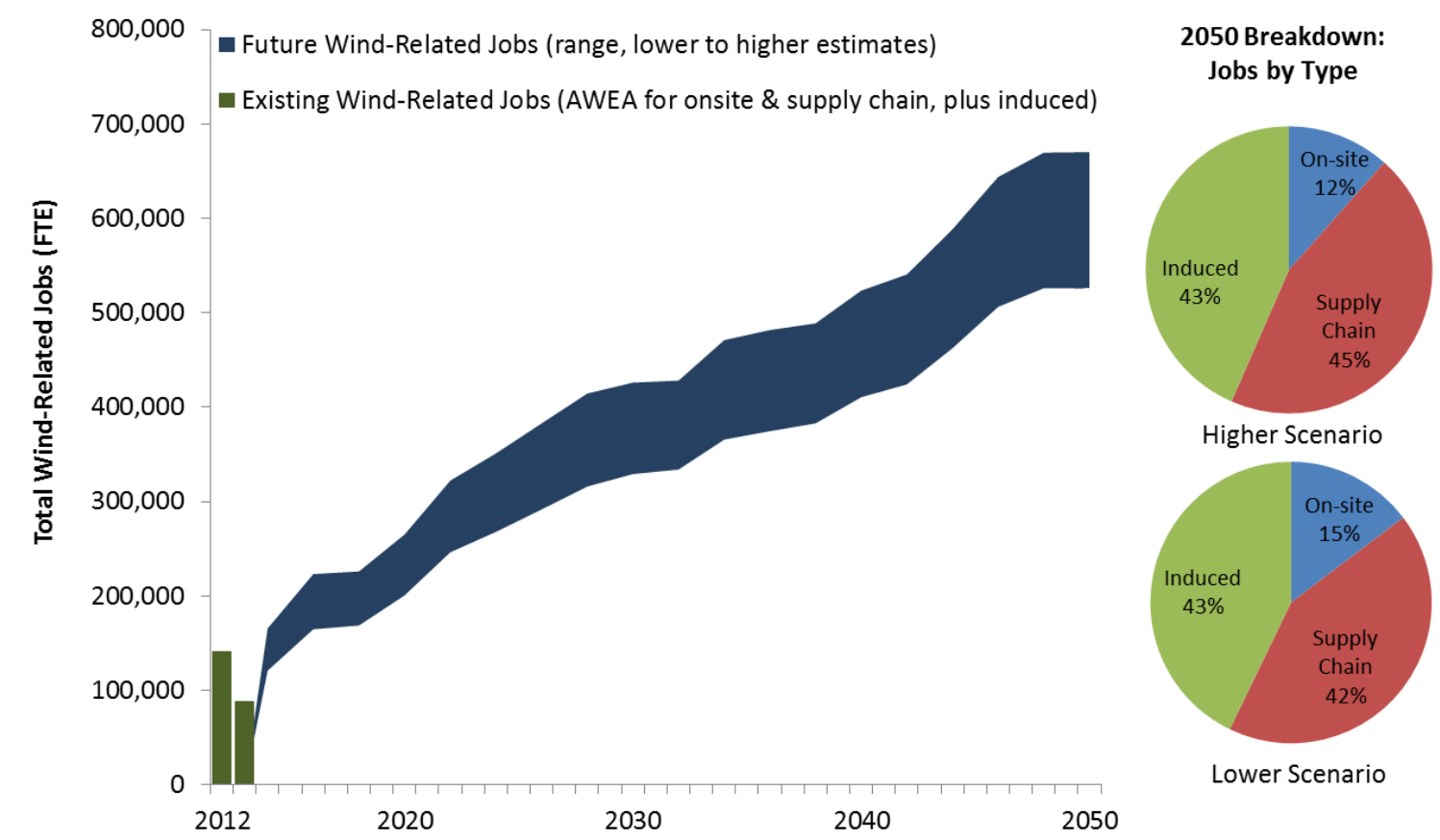

Figure 7. Wind-Related Gross Employment Estimates, including On-Site, Supply Chain, and Induced Jobs

This analysis focuses exclusively on the potential "gross" wind-related labor-force and economicdevelopment impacts of the Study Scenario-and thereby has implications for local communities surrounding wind-manufacturing facilities or projects as well as the labor-force needs of the wind industry as a whole. Our analysis does not, however, include an assessment of "net" economy-wide impacts. Increased wind generation will directly displace demand for other sources of electric generation, impacting job totals and economic development associated with those sectors. Additionally, to the extent that increased wind impacts the cost of energy, or has other macroeconomic effects, this too may affect employment in the broader economy. Studies that have evaluated the economy-wide net effects of renewable energy have shown differing results (e.g., Böhringer et al. 2013; Böhringer et al. 2012; Bowen et al. 2013; Breitschopf et al. 2011; Chien and Hu 2008; Frondel et al. 2010; Hillebrand et al. 2006; Lehr et al. 2012; Lehr et al. 2008; Marques and Fuinhas 2012; Menegaki 2011; Rivers 2013; Yi 2013). In general, however, there is little reason to believe that net impacts are likely to be sizable in either the positive or negative direction (e.g., Rivers 2013). Moreover, even were net positive effects likely, questions remain as to whether such effects serve as economic justification for government policy (e.g., Borenstein 2012; Edenhofer et al. 2013; Gillingham and Sweney 2010; Morris et al. 2012).

\subsection{Land Use and Local Impacts}

In addition to economic development, wind projects can have wide-ranging local impacts on the communities and ecosystems that surround them, including those related to land and offshore use, wildlife, aviation and radar, aesthetics and public acceptance, and health and safety. While these impacts cannot all be readily quantified, DOE (2015) provides a robust discussion of the existing literature and, where feasible, offers limited quantification.

With respect to land use, focusing on the area impacted by the turbine footprint, roads, and associated infrastructure and assuming a land-use value of $0.01 \mathrm{~km}^{2} / \mathrm{MW}$ (Denholm et al. 2009; Diffendorfer and Compton 2014), installed capacity under the Study Scenario is estimated to require approximately 3,200 $\mathrm{km}^{2}$ by 2050 (Figure 8); this area equates to less than one third of the land area occupied by U.S. golf 
courses in 2013. This transformed land is dispersed over a larger area that represents the combined boundary of the wind projects. Assuming a land-use value of $0.33 \mathrm{~km}^{2} / \mathrm{MW}$ (Denholm et al. 2009), this larger area represents $106,000 \mathrm{~km}^{2}$ by 2050 ; this area equates to almost $1.5 \%$ of the land area in the contiguous United States by 2050 (Figure 8). Most of this larger area could also be used for other purposes, such as farming or ranching, though an even larger area would be impacted visually. Assuming the same boundary use assumption, offshore wind capacity in the Study Scenario covers approximately $29,000 \mathrm{~km}^{2}$ by 2050 , only a small fraction of which would be physically transformed (Figure 8 ).

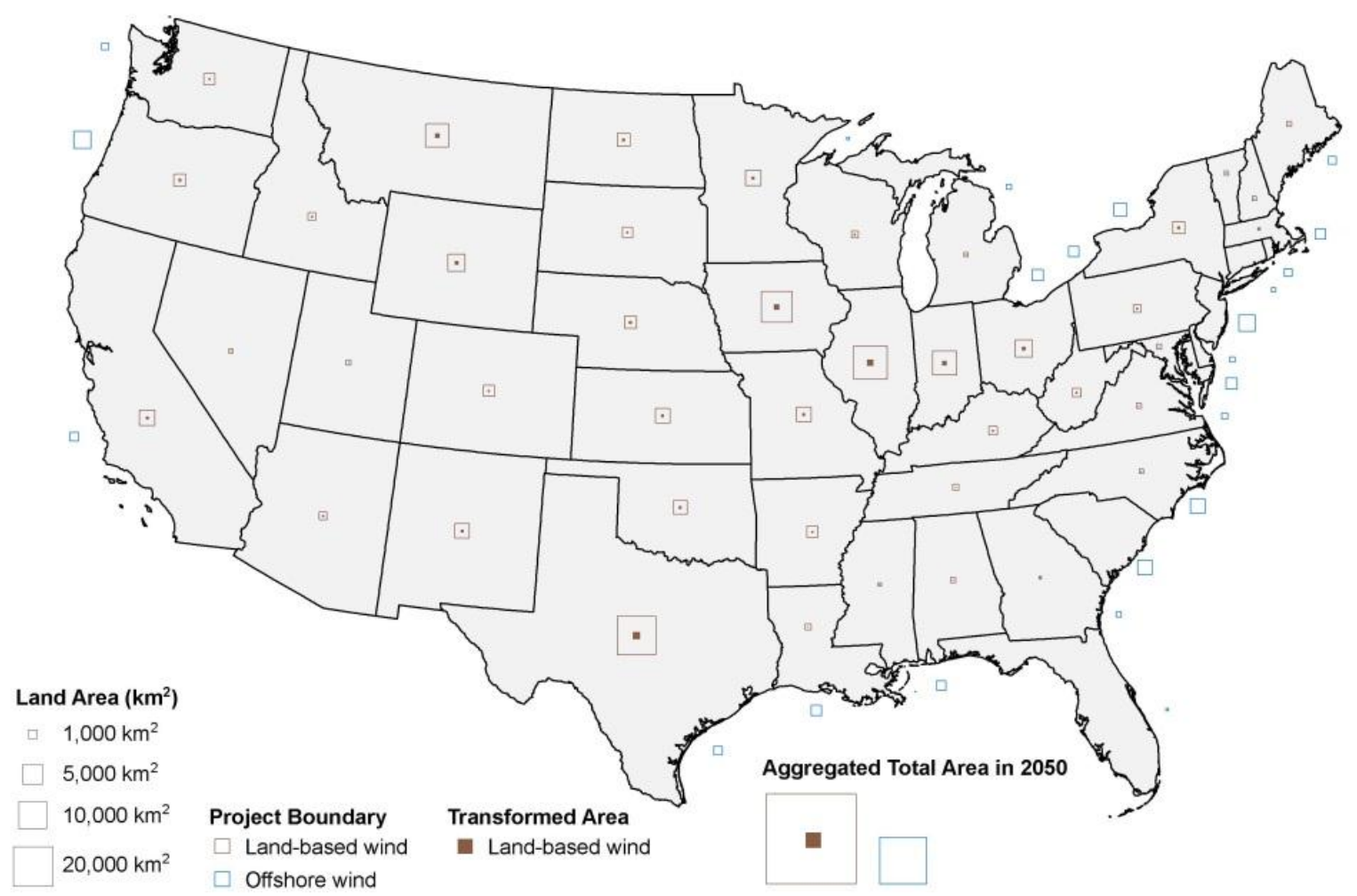

Figure 8. Land-Based and Offshore Area Requirements for Study Scenario, 2050

Given this land and ocean use and related impacts, continued wind deployment will need to be executed with sensitivity to its potential implications for avian, bat, and other wildlife populations; the local environment; the landscape; and the nearby communities, industries, infrastructure, and individuals. DOE (2015) provides a summary of these impacts and related mitigation measures.

While it is tempting to discuss these issues as "costs" of wind development, it is important to recognize that there are offsetting benefits to consider in that wind energy will displace other forms of generation, which have their own set of lifecycle land-use requirements and local impacts. The magnitude and nature of these impacts are diverse, making comparisons among different energy sources challenging. Nonetheless, these offsetting displacement benefits may be significant. For example, Fthenakis and Kim (2009) find that the lifecycle land disturbance of wind is lower than that of coal-fired generation.

\section{Conclusions}

Wind-industry proponents often point to societal attributes such as lower GHG emissions and rural economic-development opportunities as a basis for deployment of wind power. Critics argue that the costs of wind energy offset the potential benefits and that managing non-dispatchable variable 
generation is a challenging task. This paper and its companion (Lantz et al. forthcoming) inform both perspectives by providing a detailed accounting of various impacts associated with wind deployment.

Specifically, we model scenarios of the U.S. electric sector with sustained growth in wind power such that wind generation reaches $10 \%$ of end-use electricity demand in $2020,20 \%$ in 2030 , and $35 \%$ in 2050 ; we then compare those scenarios with others in which no new wind power is deployed, in order to assess the full costs, benefits, and impacts of all new wind deployment under the high-penetration scenarios. As shown in DOE (2015) and Lantz et al. (forthcoming), achieving these penetration levels would have profound implications for the wind industry and the broader electric sector. Additionally, compared to the baseline that assumes no new wind deployment post-2013-and under our central assumptions -achieving these specified wind penetrations imposes a cost increase $(<1 \%)$ on electricity consumers in the 2020 and 2030 timeframes, but longer-term savings after 2030 are possible. On a present-value basis over the 2013 to 2050 period, Lantz et al. (forthcoming) report potential incremental electricity-sector expenditures that range from savings of $\$ 388$ billion to a cost increase of $\$ 254$ billion.

The possible impacts of such wind-deployment scenarios on electric-sector costs should be balanced against the variety of compensating environmental and social implications. In particular, our analysis shows potential GHG benefits of $\$ 85-\$ 1,230$ billion, with a central estimate of roughly $\$ 400$ billion. Airpollution-related health benefits are estimated at $\$ 52-\$ 272$ billion, while annual electric-sector water withdrawals and consumption are lower by $15 \%$ and $23 \%$ in 2050 , respectively. We also find that a highwind-energy future would have implications for the diversity and risk of energy supply, local economic development and jobs, and land use and related local impacts. While these considerations may inform decision makers, we treat them as "impacts," not "benefits" or "costs," because they-to a degreerepresent resource transfers and so may not greatly affect aggregate social welfare.

In sum, this analysis, in concert with the analysis in Lantz et al. (forthcoming), find that a future U.S. electricity system in which wind plays a major role is plausible; could result in enduring benefits globally, nationally, and locally; and could result in consumer and system cost savings in the long term. At the same time, we find that near- to medium-term cost barriers must be overcome along with a host of local environmental and societal implications of wind-project development.

In addition to formulating and applying state-of-the-art methods to evaluate the costs, benefits, and impacts of high wind penetrations in the United States, there are two practical applications of the methods and findings reported here. First, the results can inform policy interventions intended to overcome the near- and medium-term cost barriers noted above. In the United Stated, various policies have been used to support wind deployment-from federal tax incentives and proposed carbon regulations, to state-level renewables portfolio standards and other types of financial incentives (DOE 2015). The analysis presented here and in Lantz et al. (forthcoming) suggests that some subset of these policies will continue to be needed in the near- to medium-term in order to overcome cost barriers and enable continued wind deployment growth, and that those policies may be justified by the societal benefits associated with wind deployment. Second, the comprehensive set of methods assembled for the analysis presented here, with associated caveats, might be usefully applied in other contexts and regions. In particular, similar tools might be applied at a local level to inform wind deployment efforts, or in other countries to inform their wind deployment efforts, or to other technologies beyond wind.

Finally, we note that while this analysis seeks to inform policy as discussed above, it does not suggest any specific type of policy. The specific costs and benefits of increased wind development will be impacted by the nature of the policy and market levers used to encourage that development; as such, 
the present work suggests the general magnitude of these impacts only. Related research has found that policies specifically designed to internalize external costs and correct for market failures are likely to be more cost effective than technology- or sector-specific policy incentives, in part due to possible economy-wide rebound and spillover effects and also because such policies more-directly target the achievement of public benefits (Borenstein 2012; Edenhofer et al. 2013; Fischer and Newell 2008; Fell and Linn 2013; IPCC 2011; IPCC 2014b; Kalkuhl et al.2013; McKibbin et al. 2014; Novan 2014; Rausch and Karplus 2014; Tuladhar et al. 2014). Therefore, while the present analysis may suggest a significantly positive role for wind energy, achieving those benefits to the maximum and most cost-effective degree is likely to require a policy framework that moves away from direct support of wind to one that more effectively and more broadly addresses key market failures and unpriced externalities.

\section{Acknowledgements}

We thank the many contributors to the analysis described in this paper: Ian Baring-Gould (NREL), Alberta Carpenter (NREL), Stuart Cohen (NREL), Ed Demeo (consultant), Edward Eugeni (SRA International), Thomas Jenkin (NREL), Venkat Krishnan (NREL), Jessica Lin-Powers (NREL), Jeff Logan (NREL), Andrew Mills (Lawrence Berkeley National Laboratory), David Mulcahy (formerly NREL), Brian Naughton (Sandia), Arman Shehabi (Lawrence Berkeley National Laboratory), Suzanne Tegen (NREL), Rich Tusing (New West Energy), and Jose Zayas (DOE). This work was supported by DOE's Office of Energy Efficiency and Renewable Energy (Wind and Water Power Technologies Office) under Contract No. DE-AC02$05 \mathrm{CH} 11231$. The opinions represented in this article are the authors' own and do not reflect the view of DOE or the U.S. Government. Any errors are the responsibility of the authors. 


\section{References}

Ackerman, F. and E.A. Stanton (2012). "Climate Risks and Carbon Prices: Revising the Social Cost of Carbon." Economics: The Open-Access, Open-Assessment E-Journal. doi: 10.5018/economicsejournal.ja.2012-10.

Arent, D., J. Pless, T. Mai, R. Wiser, M. Hand, S. Baldwin, G. Heath, J. Macknick, M. Bazilian, A. Schlosser and P. Denholm (2014). "Implications of High Renewable Electricity Penetration in the US for Water Use, Greenhouse Gas Emissions, Land-Use, and Materials Supply." Applied Energy 123: 368-77.

Arrow, K., M. Cropper, C. Gollier, B. Groom, G. Heal, R. Newell, W. Nordhaus, R. Pindyck, W. Pizer, P. Portney, T. Sterner, R.S.J. Tol, and M. Weitzman (2013). "Determining Benefits and Costs for Future Generations." Science 341(6144): 349-350. doi: 10.1126/science.1235665.

Averyt, K., J. Fisher, A. Huber-Lee, A. Lewis, J. Macknick, N. Madden, J. Rogers, and S. Tellinghuisen (2011). Freshwater Use by U.S. Power Plants: Electricity's Thirst for a Precious Resource. Union of Concerned Scientists.

Averyt, K., J. Meldrum, P. Caldwell, G. Sun, S. McNulty, A. Huber-Lee, and N. Madden (2013). "Sectoral Contributions to Surface Water Stress in the Coterminous United States." Environmental Research Letters 8(3): 035046. doi: 10.1088/1748-9326/8/3/035046.

Awerbuch, S. (1993). "The Surprising Role of Risk in Utility Integrated Resource Planning." The Electricity Journal 6(3): 20-33. doi: 10.1016/1040-6190(93)90048-P.

Awerbuch, S. and M. Berger (2003). Applying Portfolio Theory to EU Electricity Planning and PolicyMaking. IEA/EET Working Paper EET/2003/03. Paris: International Energy Agency.

Barbose, G., R. Wiser, A. Phadke, and C. Goldman (2008). "Managing Carbon Regulatory Risk in Utility Resource Planning: Current Practices in the Western United States." Energy Policy 36(9): 3300-3311. doi: 10.1016/j.enpol.2008.04.023.

Barthelmie, R.J. and S.C. Pryor (2014). "Potential contribution of wind energy to climate change mitigation." Nature Climate Change 4: 684-688.

Bazilian, M. and F. Roques, eds. (2008). Analytical Methods for Energy Diversity \& Security. Elsevier Global Energy Policy and Economics Series. Oxford: Elsevier.

Bell, M.L., A. McDermott, S.L. Zeger, J.M. Samet, and F. Dominici (2004). “Ozone and Short-term Mortality in 95 US Urban Communities, 1987-2000." Journal of the American Medical Association 292(19): 2372-2378.

Böhringer, C., A. Keller, and E. van der Werf (2013). "Are Green Hopes Too Rosy? Employment and Welfare Impacts of Renewable Energy Promotion." Energy Economics 36(March): 277-285. doi: 10.1016/j.eneco.2012.08.029.

Böhringer, C., N.J. Rivers, T.F. Rutherford, and R. Wigle (2012). "Green Jobs and Renewable Electricity Policies: Employment Impacts of Ontario's Feed-in Tariff." The B.E. Journal of Economic Analysis \& Policy 12(1).

Bokenkamp, K., H. LaFlash, V. Singh, and D. Bachrach Wang (2005). "Hedging Carbon Risk: Protecting Customers and Shareholders from the Financial Risk Associated with Carbon Dioxide Emissions." The Electricity Journal 18(6): 11-24. doi: 10.1016/j.tej.2005.05.007. 
Bolinger, M. (2013). Revisiting the Long-Term Hedge Value of Wind Power in an Era of Low Natural Gas Prices. LBNL-6103E. Berkeley, CA: Lawrence Berkeley National Laboratory.

Bolinger, M., R. Wiser, and W. Golove (2006). "Accounting for Fuel Price Risk When Comparing Renewable to Gas-Fired Generation: The Role of Forward Natural Gas Prices." Energy Policy 34(6): 706720. doi: 10.1016/j.enpol.2004.07.008.

Borenstein, S. (2012). "The Private and Public Economics of Renewable Electricity Generation." Journal of Economic Perspectives 26(1): 67-92. doi: 10.1257/jep.26.1.67.

Bowen, W.M., S. Park, and J.A. Elvery (2013). "Empirical Estimates of the Influence of Renewable Energy Portfolio Standards on the Green Economies of States." Economic Development Quarterly (June): 0891242413491316. doi: 10.1177/0891242413491316.

Breitschopf, B., C. Nathani, and G. Resch (2011). Review of Approaches for Employment Impact Assessment of Renewable Energy Deployment. International Energy Agency, Renewable Energy Technology Deployment.

Brown, J.P., J. Pender, R. Wiser, E. Lantz, and B. Hoen (2012). "Ex Post Analysis of Economic Impacts from Wind Power Development in U.S. Counties." Energy Economics 34(6): 1743-1754. doi: 10.1016/j.eneco.2012.07.010.

Brown, K.E., D.K. Henze, and J.B. Milford (2013). "Accounting for climate and air quality damages in future electricity generation scenarios" Environmental Science and Technology 47: 3065-3072.

Buonocore, J., P. Luckow, G. Norris, J. Spengler, B. Biewald, J. Fisher and J. Levy (2016). "Health and Climate Benefits of Different Energy-Efficiency and Renewable Energy Choices." Nature Climate Change 6, 100-105.

Chandel, M.K., L.F. Pratson, and R.B. Jackson (2011). "The Potential Impacts of Climate-Change Policy on Freshwater Use in Thermoelectric Power Generation." Energy Policy 39(10): 6234-6242. doi: 10.1016/j.enpol.2011.07.022.

Chien, T. and J.L. Hu (2008). "Renewable Energy: An Efficient Mechanism to Improve GDP." Energy Policy 36(8): 3045-3052. doi: 10.1016/j.enpol.2008.04.012.

Cleveland, C.J., R. Ayeares, R. Costanza, J. Goldemberg, M.D. Ilic, E. Jochem, R. Kaufmann, A. Lovins, M. Munasinghe, C. Sheinbaum Pardo, P. Peterson, L. Schipper, M.E. Slade, V. Smil, E. Worrell, and R.K. Pachauri (2004). Encyclopedia of Energy. San Diego: Elsevier Science \& Technology Books.

Cochran, J., T. Mai and M. Bazilian (2014). "Meta-analysis of high-penetration renewable energy scenarios." Renewable and Sustainable Energy Reviews 29: 246-253.

Cullen, J. (2013). "Measuring the Environmental Benefits of Wind-Generated Electricity." American Economic Journal: Economic Policy 5(4): 107-133. doi: 10.1257/pol.5.4.107.

Denholm, P., M. Hand, M. Jackson, and S. Ong (2009). Land Use Requirements of Modern Wind Power Plants in the United States. NREL Report No. TP-6A2-45834. Golden, CO: National Renewable Energy Laboratory.

Denny, E. and M. O'Malley (2006). “Wind Generation, Power System Operation, and Emissions Reduction." Power Systems, IEEE Transactions on 21(1): 341-347. doi: 10.1109/TPWRS.2005.857845.

Diffendorfer, J.E. and R.W. Compton (2014). "Land Cover and Topography Affect the Land Transformation Caused by Wind Facilities." PLOS ONE 9(2): e88914. doi: 10.1371/journal.pone.0088914. 
DOE (U.S. Department of Energy) (2008). 20\% Wind Energy by 2030: Increasing Wind Energy's Contribution to U.S. Electricity Supply. Washington D.C.: U.S. Department of Energy.

DOE (U.S. Department of Energy) (2013). U.S. Energy Sector Vulnerabilities to Climate Change and Extreme Weather. Washington, DC: U.S. Department of Energy.

DOE (U.S. Department of Energy) (2015). Wind Vision: A New Era for Wind Power in the United States. Washington, DC: U.S. Department of Energy.

Driscoll, C.T., J.J. Buonocore, J.I. Levy, K.F. Lambert, D. Burtraw, S.B. Reid, H. Fakhraei, and J. Schwartz (2015). "US power plant carbon standards and clean air health co-benefits." Nature Climate Change. doi: 10.1038/NCLIMATE2598.

Druckenmiller, H. (2012). At Wind Speed: How the U.S. Wind Industry Is Rapidly Growing Our Local Economies. IP: 12-09-A. New York: Natural Resources Defense Council.

Edenhofer, O., L. Hirth, B. Knopf, M. Pahle, S. Schlömer, E. Schmid, and F. Ueckerdt (2013). "On the Economics of Renewable Energy Sources." Energy Economics 40(Supplement 1, December): S12-S23. doi: 10.1016/j.eneco.2013.09.015.

EPA (U.S. Environmental Protection Agency) (2013). 2012 Progress Report: SO2 and NOx Emission, Compliance, and Market Analysis. Washington D.C.: U.S. Environmental Protection Agency.

EPA (U.S. Environmental Protection Agency) (2014). Standards of Performance for Greenhouse Gas Emissions From New Stationary Sources: Electric Utility Generating Units: Proposed Rule. Washington D.C.: Federal Register.

European Commission (2003). External Costs: Research Results on Socio-Environmental Damages Due to Electricity and Transport. EUR 20198. Brussels: European Commission.

Fann, N., K.R. Baker, and C.M. Fulcher (2012). "Characterizing the PM2.5-related health benefits of emission reductions for 17 industrial, area and mobile emission sectors across the U.S." Environment International: 141-151.

Fann, N., C.M. Fulcher, and B.J. Hubbell (2009). "The influence of location, source, and emission type in estimates of the human health benefits of reducing a ton of air pollution." Air Quality Atmospheric Health 2: 169-176.

Fell, H. and J. Linn (2013). "Renewable Electricity Policies, Heterogeneity, and Cost Effectiveness." Journal of Environmental Economics and Management 66(3): 688-707. doi: 10.1016/j.jeem.2013.03.004.

Fischer, C. and R.G. Newell (2008). "Environmental and Technology Policies for Climate Mitigation." Journal of Environmental Economics and Management 55(2): 142-162. doi: 10.1016/j.jeem.2007.11.001.

Flores, F., D. Keyser, and S. Tegen (2014). Potential Economic Impacts from Offshore Wind in the Gulf of Mexico Region. DOE/GO-102014-3857. Golden, CO: National Renewable Energy Laboratory.

Fripp, M. (2011). "Greenhouse Gas Emissions from Operating Reserves Used to Backup Large-Scale Wind Power." Environmental Science \& Technology 45(21): 9405-9412. doi: 10.1021/es200417b.

Frondel, M., N. Ritter, C.M. Schmidt, and C. Vance (2010). "Economic Impacts from the Promotion of Renewable Energy Technologies: The German Experience." Energy Policy 38(8): 4048-4056. doi: 10.1016/j.enpol.2010.03.029.

Fthenakis, V. and H.C. Kim (2010). "Life-Cycle Uses of Water in U.S. Electricity Generation." Renewable and Sustainable Energy Reviews 14(7): 2039-2048. doi: 10.1016/j.rser.2010.03.008. 
Fthenakis, V. and H.C. Kim (2009). "Land use and electricity generation: A life-cycle analysis." Renewable and Sustainable Energy Reviews 13(6-7): 1465-1474.

GAO (Government Accountability Office) (2014). Regulatory Impact Analysis: Development of Social Cost of Carbon Estimates. GAO-14-663. Washington, D.C.: Government Accountability Office.

GAO (Government Accountability Office) (2004). Wind Power's Contribution to Electric Power Generation and Impact on Farms and Rural Communities. GAO-04-756. Washington, D.C.: Government Accountability Office.

GE Energy Consulting (2014). PJM Renewable Integration Study. Schenectady, NY: General Electric Energy Consulting Group. Report for PJM Interconnection.

Gillingham, K. and J. Sweney (2010). "Market Failure and the Structure of Externalities." In Harnessing Renewable Energy. Washington D.C.: RFF Press.

Göransson, L. and F. Johnsson (2009). "Dispatch Modeling of a Regional Power Generation System Integrating Wind Power." Renewable Energy 34(4): 1040-1049. doi: 10.1016/j.renene.2008.08.002.

Graff Zivin, J.S., M.J.Kotchen, and E. Mansur (2014). "Spatial and temporal heterogeneity of marginal emissions: Implications for electric cars and other electricity-shifting policies." Journal of Economic Behavior \& Organization 107: 248-268. doi: 10.1016/j.jebo.2014.01.010.

Gross, R., P. Heptonstall, D. Anderson, T. Green, M. Leach, and J. Skea (2006). The Costs and Impacts of Intermittency: An Assessment of the Evidence on the Costs and Impacts of Intermittent Generation on the British Electricity Network. London: Imperial College London, UK Energy Research Centre.

GWEC (Global Wind Energy Council) (2015). Global Wind Report: Annual Market Update 2014. Brussels: Global Wind Energy Council.

Heeter, J., G. Barbose, L. Bird, S. Weaver, F. Flores, K. Kuskove-Burns, and R. Wiser (2014). Estimating the Costs and Benefits of Complying with Renewable Portfolio Standards: Reviewing Experience to Date. Golden, CO: National Renewable Energy Laboratory.

Hillebrand, B., H.G. Buttermann, J.M. Behringer, and M. Bleuel (2006). "The Expansion of Renewable Energies and Employment Effects in Germany." Energy Policy 34(18): 3484-3494. doi:

10.1016/j.enpol.2005.06.017.

IPCC (2007a). Climate Change 2007: Impacts, Adaptation and Vulnerability: Contribution of Working Group II to the Fourth Assessment Report of the Intergovernmental Panel on Climate Change.

Cambridge: Cambridge University Press.

IPCC (2007b). Climate Change 2007: Mitigation of Climate Change: Contribution of Working Group III to the Fourth Assessment Report of the Intergovernmental Panel on Climate Change. Cambridge:

Cambridge University Press.

IPCC (2007c). Climate Change 2007: The Physical Science Basis: Working Group I Contribution to the Fourth Assessment Report of the IPCC. 1 Pap/Cdr. Cambridge: Cambridge University Press.

IPCC (2011). IPCC Special Report on Renewable Energy Sources and Climate Change Mitigation. Prepared by Working Group III of the Intergovernmental Panel on Climate Change. Cambridge: Cambridge University Press.

IPCC (2013). Climate Change 2013: The Physical Science Basis: Working Group I Contribution to the Fifth Assessment Report of the IPCC. Cambridge: Cambridge University Press. 
IPCC (2014a). Climate Change 2014: Impacts, Adaptation, and Vulnerability: Working Group II Contribution to the Fifth Assessment Report of the IPCC. Cambridge: Cambridge University Press.

IPCC (2014b). Climate Change 2014: Mitigation of Climate Change: Working Group III Contribution to the Fifth Assessment Report of the IPCC. Cambridge: Cambridge University Press.

IWG (2010). Technical Support Document: Social Cost of Carbon for Regulatory Impact Analysis Under Executive Order 12866. Washington D.C.: Interagency Working Group on Social Cost of Carbon.

IWG (2013). Technical Support Document: Technical Update of the Social Cost of Carbon for Regulatory Impact Analysis Under Executive Order 12866. November 2013 Revision. Washington D.C.: Interagency Working Group on Social Cost of Carbon.

Jakob, M., M. Haller, and R. Marschinski (2012). "Will History Repeat Itself? Economic Convergence and Convergence in Energy Use Patterns." Energy Economics. doi:10.1016/j.eneco.2011.07.008.

Jenkin, T., V. Diakov, E. Drury, B. Bush, P. Denholm, J. Milford, D. Arent, R. Margolis, and R. Byearne (2013). The Use of Solar and Wind as a Physical Hedge against Price Variability within a Generation Portfolio. NREL/TP-6A20-59065. Golden, CO: National Renewable Energy Laboratory.

Johnson, L.T. and C. Hope (2012). "The Social Cost of Carbon in U.S. Regulatory Impact Analyses: An Introduction and Critique." Journal of Environmental Studies and Sciences 2(3): 205-221. doi:.10.1007/s13412-012-0087-7.

Johnson, L.T., S. Yeh, and C. Hope (2013). "The Social Cost of Carbon: Implications for Modernizing Our Electricity System." Journal of Environmental Studies and Sciences 3(4): 369-375. doi: 10.1007/s13412013-0149-5.

Kaffine, D., B. McBee, and J. Lieskovsky (2013). "Emissions savings from wind power generation in Texas." The Energy Journal 34(1): 155-175.

Kalkuhl, M., O. Edenhofer, and K. Lessman (2013). "Renewable Energy Subsidies: Second-Best Policy or Fatal Aberration for Mitigation?" Resource and Energy Economics 35(3): 217-234. doi:

dx.doi.org/10.1016/j.reseneeco.2013.01.002.

Kenny, J.F., N.L. Barber, S.S. Hutson, K.S. Linsey, J.K. Lovelace, and M.A. Maupin (2009). Estimated Use of Water in the United States in 2005. CIR - 1344. Washington, D.C.: United States Geological Survey.

Keyser, D., S. Tegen, F. Flores, D. Zammit, M. Kraemer, and J. Miles (2014). Potential Economic Impacts from Offshore Wind in the Mid-Atlantic Region. DOE/GO-102014-4359. Golden, CO: National Renewable Energy Laboratory.

Kopp, R.E., A. Golub, N.O. Keohane, and C. Onda (2012). "The Influence of the Specification of Climate Change Damages on the Social Cost of Carbon." Economics: The Open-Access, Open-Assessment EJournal. doi: 10.5018/economics-ejournal.ja.2012-13.

Kopp, R.E. and B.K. Mignone (2012). "The U.S. Government's Social Cost of Carbon Estimates after Their First Two Years: Pathways for Improvement." Economics: The Open-Access, Open-Assessment E-Journal. doi: 10.5018/economics-ejournal.ja.2012-15.

Krewitt, W. and B. Schlomann (2006). Externe Kosten Der Stromerzeugung Aus Erneuerbaren Energien Im Vergleich Zur Stromerzeugung Aus Fossilen Energieträgern. DLR, Institut für Technische Thermodynamik, Fraunhofer Institut für System-und Innovationsforschung, Gutachten im Auftrag des ZSW im Rahmen von Beratungsleistungen für das BMU. 
Krewski, D., M. Jerrett, R.T. Burnett, R. Ma, E. Hughes, Y. Shi, M.C. Turner, C. Arden Pope III, G. Thurston, E.E. Calle, and M.J. Thun (2009). Extended Follow-Up and Spatial Analysis of the American Cancer Society Study Linking Particulate Air Pollution and Mortality. HEI Research Report, 140. Boston, MA: Health Effects Institute.

Lantz, E., T. Mai, R. Wiser, and V. Krishnan (forthcoming). "Long-term Implications of Sustained Wind Power Growth in the United States: Direct Electric System Impacts and Costs." Economic of Energy and Environmental Policy.

Lantz, E. and S. Tegen (2008). Variables Affecting Economic Development of Wind Energy. NREL Report No. CP-500-43506. Golden, CO: National Renewable Energy Laboratory.

Lehr, U., C. Lutz, and D. Edler (2012). "Green Jobs? Economic Impacts of Renewable Energy in Germany." Energy Policy 47(August): 358-364. doi: 10.1016/j.enpol.2012.04.076.

Lehr, U., J. Nitsch, M. Kratzat, C. Lutz, and D. Edler (2008). "Renewable Energy and Employment in Germany." Energy Policy 36(1): 108-117. doi: 10.1016/j.enpol.2007.09.004.

Lepeule, J., L. Francine, D. Douglas, and J. Schwartz (2012). "Chronic exposure to fine particles and mortality: an extended follow-up of the Harvard Six Cities study from 1974 to 2009." Environmental Health Perspectives 120(7): 965-970.

Levy, J.I., S.M. Chemerynski, and J.A. Sarnat (2005). "Ozone Exposure and Mortality: An Empiric Bayes Metaregression Analysis." Epidemiology 16(4): 458-468.

Lew, D., G. Brinkman, E. Ibanez, A. Florita, M. Heaney, B.-M. Hodge, M. Hummon, G. Stark, J. King, and S.A. Lefton (2013). The Western Wind and Solar Integration Study Phase 2. NREL/TP-5500-55588.

Golden, CO: National Renewable Energy Laboratory.

Loomis, D. and J. Carter (2011). "Wind Development Provides the Most Jobs of the Various Generation Sources in Illinois." Center for Renewable Energy Working Paper 11: 02. Normal, IL: Illinois State University.

Luckow, P., E. Stanton, B. Biewald, J. Fisher, F. Ackerman, and E. Hausman (2013). 2013 Carbon Dioxide Price Forecast. Cambridge, MA: Synapse Energy Economics, Inc.

Luderer, G., R.C. Pietzcker, C. Bertram, E. Kriegler, M. Meinshausen, and O. Edenhofer (2013). "Economic Mitigation Challenges: How Further Delay Closes the Door for Achieving Climate Targets." Environmental Research Letters 8(3): 034033. doi: 10.1088/1748-9326/8/3/034033.

Luderer, G., V. Krey, K. Calvin, J. Merrick, S. Mima, R. Pietzcker, J. Van Vliet and K. Wada (2014). "The role of renewable energy in climate stabilization: results from the EMF27 scenarios." Climatic Change 123: 427-441.

Machol, B. and S. Rizk (2013). "Economic value of U.S. fossil fuel electricity health impacts." Environment International 52: 75-80.

MacDonald, A., C.T.M. Clack, A. Alexander, A. Dunbar, J. Wilczak and Y. Xie (2016). "Future cost-

competitive electricity systems and their impact on US CO2 emissions." Nature Climate Change. Advance online publication.

Macknick, J., R. Newmark, G. Heath, and K.C. Hallett (2012a). "Operational Water Consumption and Withdrawal Factors for Electricity Generating Technologies: A Review of Existing Literature."

Environmental Research Letters 7(4): 045802. doi: 10.1088/1748-9326/7/4/045802. 
Macknick, J., S. Sattler, K. Averyt, S. Clemmer, and J. Rogers (2012b). "The Water Implications of Generating Electricity: Water Use across the United States Based on Different Electricity Pathways through 2050." Environmental Research Letters 7(4): 045803. doi: 10.1088/1748-9326/7/4/045803.

Mai, T., R. Wiser, D. Sandor, G. Brinkman, G. Heath, P. Denholm, D. Hostick, N. Darghouth, A. Schlosser, and K. Strzepek (2012). Exploration of High Penetration Renewable Electricity Futures. Vol. 1 of Renewable Electricity Futures Study. NREL/TP-6A20-52409-1. Golden, CO: National Renewable Energy Laboratory.

Marques, A.C. and J.A. Fuinhas (2012). "Is Renewable Energy Effective in Promoting Growth?" Energy Policy 46(0): 434-442. doi: 10.1016/j.enpol.2012.04.006.

Marvel, K., B. Kravitz and K. Caleira (2012). "Geophysical limits to global wind power." Nature Climate Change 3: 118-121.

Masanet, E., Y. Chang, A.R. Gopal, P. Larsen, W.R. Morrow, R. Sathre, A. Shehabi, and P. Zhai (2013). "Life-Cycle Assessment of Electric Power Systems." Annual Review of Environment and Resources 38(1): 107-136. doi: 10.1146/annurev-environ-010710-100408.

Maulbetsch, J.S. and M.N. DiFilippo (2006). Cost and Value of Water Use at Combined Cycle Power Plants. PIER Energy-Related Environmental Research, CEC-500-2006-034. Sacramento: California Energy Commission.

McCubbin, D. and B.K. Sovacool (2013). "Quantifying the Health and Environmental Benefits of Wind Power to Natural Gas." Energy Policy 53(February): 429-441. doi: 10.1016/j.enpol.2012.11.004.

McKibbin, W.J., A.C. Morris, and P.J. Wilcoxen (2014). "Pricing Carbon in the U.S.: A Model-Based Analysis of Power-Sector-Only Approaches." Resource and Energy Economics 36(1): 130-150. doi: 10.1016/j.reseneeco.2013.11.007.

Meldrum, J., S. Nettles-Anderson, G. Heath, and J. Macknick (2013). "Life Cycle Water Use for Electricity Generation: A Review and Harmonization of Literature Estimates." Environmental Research Letters 8(1): 015031. doi: 10.1088/1748-9326/8/1/015031.

Melillo, J.M., T.C. Richmond, and G.W. Yohe (2014). Climate Change Impacts in the United States: The Third National Climate Assessment. Washington D.C.: U.S. Global Change Research Program.

Menegaki, A.N (2011). "Growth and Renewable Energy in Europe: A Random Effect Model with Evidence for Neutrality Hypothesis." Energy Economics 33(2): 257-263. doi: 10.1016/j.eneco.2010.10.004.

Morris, A.C., P.S. Nivola, and C.L. Schultze (2012). "Clean Energy: Revisiting the Challenges of Industrial Policy." Energy Economics 34, Supplement 1(0): S34-S42. doi: 10.1016/j.eneco.2012.08.030.

Muller, N.Z., R. Mendelsohn, and W. Nordhaus (2011). "Environmental Accounting for Pollution in the United States Economy." American Economic Review 101(5): 1649-1675. doi: 10.1257/aer.101.5.1649.

Navigant (2013). Offshore Wind Market and Economic Analysis: Annual Market Assessment. DE EE0005360. Washington, D.C.: U.S. Department of Energy.

Nordhaus, W.D (2013). The Climate Casino: Risk, Uncertainty, and Economics for a Warming World. New Haven, CT: Yale University Press.

Novan, K. (2014). Valuing the Wind: Renewable Energy Policies and Air Pollution Avoided. Working paper. Davis, California: University of California, Davis. 
NRC (National Research Council) (2010). Hidden Costs of Energy: Unpriced Consequences of Energy Production and Use. Washington D.C.: National Academies Press.

Oates, D.L. and P. Jaramillo (2013). "Production Cost and Air Emissions Impacts of Coal Cycling in Power Systems with Large-Scale Wind Penetration." Environmental Research Letters 8(2): 024022. doi: 10.1088/1748-9326/8/2/024022.

Pedden, M. (2006). Economic Impacts of Wind Applications in Rural Communities. NREL/SR-500-39099. Golden, CO: National Renewable Energy Laboratory.

Pehnt, M., M. Oeser, and D.J. Swider (2008). "Consequential Environmental System Analysis of Expected Offshore Wind Electricity Production in Germany." Energy 33(5): 747-759. doi:

10.1016/j.energy.2008.01.007.

Perez-Arriaga, I.J. and C. Batlle (2012). "Impacts of Intermittent Renewables on Electricity Generation System Operation." Economics of Energy \& Environmental Policy 1(2). doi: 10.5547/2160-5890.1.2.1.

Pindyck, R.S. (2013). “Climate Change Policy: What Do the Models Tell Us?” Journal of Economic Literature 51(3): 860-872.

Preiss, P. (2009). Report on the Application of the Tools for Innovative Energy Technologies. Deliverable No. 7.2 - RS 1b. Rome: New Energy Externalities Developments for Sustainability (NEEDS).

Rausch, S. and V. Karplus (2014). "Markets versus Regulation: The Efficiency and Distributional Impacts of U.S. Climate Policy Proposals." The Energy Journal 35(SI1):199-227.

Ricci, A. (2010). Policy Use of the NEEDS Report. Deliverable No. 5.3 - RS. Rome: New Energy Externalities Developments for Sustainability (NEEDS).

Rivers, N. (2013). "Renewable Energy and Unemployment: A General Equilibrium Analysis." Resource and Energy Economics 35(4): 467-485. doi: 10.1016/j.reseneeco.2013.04.004.

Sattler, S., J. Macknick, D. Yates, F. Flores-Lopez, A. Lopez, and J. Rogers (2012). "Linking Electricity and Water Models to Assess Electricity Choices at Water-Relevant Scales." Environmental Research Letters 7(4): 045804. doi: 10.1088/1748-9326/7/4/045804.

Schmalensee, R. and R.N. Stavins (2013). "The SO2 Allowance Trading System: The Ironic History of a Grand Policy Experiment." Journal of Economic Perspectives 27(1): 103-122. doi: 10.1257/jep.27.1.103.

Seaber, R.R., F.P. Kapinos, and G.L. Knapp (1987). Hydrologic Unit Maps. WSP - 2294. Washington, D.C.: U.S. Geological Survey.

Shindell, D. (2015). "The social cost of atmospheric release." Climate Change. doi: 10.1007/s 10584-0151343-0.

Siler-Evans, K., I.L. Azevedo, M.G. Morgan, and J. Apt (2013). "Regional Variations in the Health, Environmental, and Climate Benefits of Wind and Solar Generation." Proceedings of the National Academy of Sciences June: 201221978. doi: 10.1073/pnas.1221978110.

Slattery, M.C., E. Lantz, and B.L. Johnson (2011). "State and Local Economic Impacts from Wind Energy Projects: Texas Case Study." Energy Policy 39(12): 7930-7940. doi: 10.1016/j.enpol.2011.09.047.

Solley, W.B., R.R. Pierce, and H.A. PerIman (1998). Estimated Use of Water in the United States in 1995. CIR - 1200. Washington, D.C.: U.S. Geological Survey. 
Steinberg, D., G. Porro, and M. Goldberg (2012). Preliminary Analysis of the Jobs and Economic Impacts of Renewable Energy Projects Supported by the ..section..1603 Treasury Grant Program. NREL/TP-6A2052739. Golden, CO: National Renewable Energy Laboratory.

Stirling, A. (1994). "Diversity and Ignorance in Electricity Supply Investment: Addressing the Solution rather than the Problem." Energy Policy 22(3): 195-216. doi: 10.1016/0301-4215(94)90159-7.

Stirling, A. (2010). "Multicriteria Diversity Analysis: A Novel Heuristic Framework for Appraising Energy Portfolios." Energy Policy 38(4): 1622-1634. doi: 10.1016/j.enpol.2009.02.023.

Thompson, T.M., S. Rausch, R.K. Saari, and N.E. Selin (2014). "A systems approach to evaluating the air quality co-benefits of US carbon policies." Nature Climate Change 4(10): 917-923.

Tidwell, V.C., L.A. Malczynski, P.H. Kobos, G.T. Klise, and E. Shuster (2013). “Potential Impacts of Electric Power Production Utilizing Natural Gas, Renewables and Carbon Capture and Sequestration on U.S. Freshwater Resources." Environmental Science \& Technology 47(15): 8940-8947. doi:

10.1021/es3052284.

Tol, R.S.J. (2011). “The Social Cost of Carbon." Annual Review of Resource Economics 3(1): 419-443. doi: 10.1146/annurev-resource-083110-120028.

Tuladhar, S., S. Mankowski, and P. Bernstein (2014). "Interaction Effects of Market-Based and Command-and-Control Policies." The Energy Journal 35(SI1):61-88.

Turconi, R., A. Boldrin, and T. Astrup (2013). "Life Cycle Assessment (LCA) of Electricity Generation Technologies: Overview, Comparability and Limitations." Renewable and Sustainable Energy Reviews 28(December): 555-565. doi: 10.1016/j.rser.2013.08.013.

Valentino, L., V. Valenzuela, A. Botterud, Z. Zhou, and G. Conzelmann (2012). "System-Wide Emissions Implications of Increased Wind Power Penetration." Environmental Science \& Technology 46(7): 42004206. doi: 10.1021/es2038432.

van Vliet, M.T.H., J.R. Yearsley, F. Ludwig, S. Vogele, D.P. Lettenmaier, and P. Kabat (2012). "Vulnerability of US and European Electricity Supply to Climate Change." Nature Climate Change advance online publication (June). doi: 10.1038/nclimate1546.

Wei, M., S. Patadia, and D.M. Kammen (2010). "Putting Renewables and Energy Efficiency to Work: How Many Jobs Can the Clean Energy Industry Generate in the US?" Energy Policy 38(2): 919-931. doi: 10.1016/j.enpol.2009.10.044.

Weitzman, M.L. (2012). "GHG Targets as Insurance Against Catastrophic Climate Damages." Journal of Public Economic Theory 14(2): 221-244. doi: 10.1111/j.1467-9779.2011.01539.x.

Wiser, R. and M. Bolinger (2006). "Balancing Cost and Risk: The Treatment of Renewable Energy in Western Utility Resource Plans." The Electricity Journal 19(1): 48-59. doi: 10.1016/j.tej.2005.10.012.

Wiser, R. and M. Bolinger (2007). "Can Deployment of Renewable Energy Put Downward Pressure on Natural Gas Prices?” Energy Policy 35(1): 295-306. doi: 10.1016/j.enpol.2005.11.021.

Wiser, R. and M. Bolinger (2014). 2013 Wind Technologies Market Report. LBNL-6809E. Berkeley, CA: Lawrence Berkeley National Laboratory.

Wiser, R., Z. Yang, M. Hand, O. Hohmeyer, D. Infield, P.H. Jensen, V. Nikolaev, M. O'Malley, G. Sinden, and A. Zervos (2011). "Wind Energy." In IPCC Special Report on Renewable Energy Sources and Climate Change Mitigation. Cambridge: Cambridge University Press. 
Yang, J. and B. Chen (2016). "Emergy-based sustainability evaluation of wind power generation systems." Applied Energy 177: 239-246.Yi, H. (2013). "Clean Energy Policies and Green Jobs: An Evaluation of Green Jobs in U.S. Metropolitan Areas." Energy Policy 56: 644-652. doi:

10.1016/j.enpol.2013.01.034.

Zhai, H. and E.S. Rubin (2010). "Performance and Cost of Wet and Dry Cooling Systems for Pulverized Coal Power Plants with and without Carbon Capture and Storage." Energy Policy 38(10): 5653-5660. doi: 10.1016/j.enpol.2010.05.013.

Zhang X., C. Ma, X. Song, Y. Zhou and W. Chen (2016). "The impacts of wind technology advancement on future global energy." Applied Energy, in press, corrected proof, available online. 